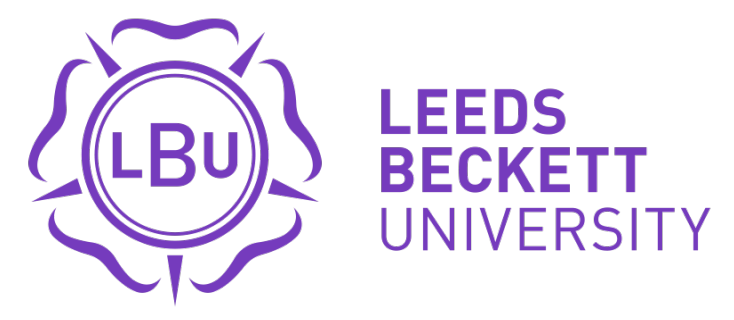

Citation:

Sharp, JG and Sharp, J and Young, E (2018) Academic boredom, engagement and the achievement of undergraduate students at university: a review and synthesis of relevant literature. Research Papers in Education. ISSN 1470-1146 DOI: https://doi.org/10.1080/02671522.2018.1536891

Link to Leeds Beckett Repository record:

https://eprints.leedsbeckett.ac.uk/id/eprint/5369/

Document Version:

Article (Accepted Version)

This is an Accepted Manuscript of an article published by Taylor \& Francis in Research Papers in Education on 26 October 2018, available online: http://www.tandfonline.com/10.1080/02671522.2018.1536891

The aim of the Leeds Beckett Repository is to provide open access to our research, as required by funder policies and permitted by publishers and copyright law.

The Leeds Beckett repository holds a wide range of publications, each of which has been checked for copyright and the relevant embargo period has been applied by the Research Services team.

We operate on a standard take-down policy. If you are the author or publisher of an output and you would like it removed from the repository, please contact us and we will investigate on a case-by-case basis.

Each thesis in the repository has been cleared where necessary by the author for third party copyright. If you would like a thesis to be removed from the repository or believe there is an issue with copyright, please contact us on openaccess@leedsbeckett.ac.uk and we will investigate on a case-by-case basis. 
Academic boredom, engagement and the achievement of undergraduate students at university: A review and synthesis of relevant literature

John G. Sharp ${ }^{1}$, Jane C. Sharp ${ }^{1}$ and Emma Young ${ }^{2}$

${ }^{1}$ Carnegie School of Education, Leeds Beckett University, Leeds LS6 3QS

${ }^{2}$ University Campus Oldham, University Way, Oldham OL1 1BB

Please direct all correspondence to the first author, Professor John G. Sharp

This article (revised) is protected until released for publication

(C) Sharp, Sharp and Young - September, 2018 


\section{Academic boredom, engagement and the achievement of undergraduate students at university: A review and synthesis of relevant literature}

\section{Abstract}

This review and synthesis of relevant literature considers the nature of boredom and boredom proneness in general terms before focusing on how the academic boredom experienced by undergraduates at university is sufficiently different from other known types to warrant a unique and important field of study. Derived from within the literature itself, academic boredom is commonly presented as a largely negative and deactivating achievement-related emotion known to impact usually adversely on student engagement and performance. Tracing traditional as well as contemporary views from psychology, which has tended to dominate the field, findings that remain largely quantitative and highly statistical in nature are exemplified alongside the more exploratory but mixedmethods and educational work recently conducted in the UK. A comparison of the questionnaire-based self-report instruments frequently used in data collection is also included. Rooted within Control-Value Theory, the implications associated with academic boredom are far from trivial, particularly with respect to understanding sites and triggers, how students respond and cope and how the overall quality of the student experience might be improved. Limitations in the work undertaken to date draw attention to opportunities for further educational and interdisciplinary research.

Key words: academic boredom, student engagement, achievement, undergraduate, Control-Value Theory

\section{A 'universal' phenomenon}

At work, rest and play

Regardless of age, gender, race and social or educational background, it would seem, boredom is a relatively common and universally experienced emotion, affecting people's daily lives in different and sometimes unexpected ways (Bardgill, 2000; Barnett, 2005; Tsapelas et al., 2009; Vodanovich et al., 2011; Harasymchuk and Fehr, 2012; Zakay, 2014; Williams, 2015; Mann, 2016; Chin et al., 2017). In workplace settings all over the world, boredom has long been associated with fooling around, making mistakes, causing accidents, absenteeism and theft, as well as contributing towards poor job satisfaction and reduced productivity (Dumas, 2001; Kass et al., 2001a; Mann, 2007; Loukidou et al., 2009; Watt and Hargis, 2010; Bruursema et al., 
2011; Keleş and Özkan, 2011; Gerritson et al., 2014; Wan et al., 2014; Shani et al., 2018). Boredom has also been recognised as a contributing factor in the general disillusionment and disaffection of pupils at school (Loken, 1973; Robinson, 1975; Fogelman, 1976; Gjesme, 1977; Vandewiele, 1980; Wasson, 1981; Tidwell, 1988; Larson, 1991; Shaw, 1996; Belton and Pryadharshini, 2007; Macklem, 2015), irrespective of ability (Newberry and Duncan, 2001; Cullingford, 2002; Fallis and Opotow, 2003; Kanevsky and Keighley, 2003; Frenzel et al., 2010; Preckel et al., 2010), and in some subjects more than others (Goetz et al., 2006a,b, 2007; Frenzel et al., 2007; Nett et al., 2010, 2011; Daschmann et al., 2011; Schukajlow and Rakoczy, 2016; Peixoto et al., 2017), frequently resulting in loneliness and withdrawal, feelings of confinement and disempowerment, tiredness and fatigue, classroom disruption, feigned illness, truancy, high-risk or even dangerous activities and a general decline in grades (McGiboney and Carter, 1988; Paulson et al., 1990; Iso-Ahola and Crowley, 1991; Caldwell et al., 1999; Amos et al., 2006; Chien-Hsin et al., 2009; Miller et al., 2014; Altay and Coskun, 2016; Nett et al., 2016; Putwain, 2017).

\section{At university}

Surprisingly perhaps, undergraduate students also get bored at university. Despite success in securing a place to study at a location of choice, university does not always provide the personal, social and intellectual stimulation needed to keep every student actively engaged. The everyday signs of academic boredom, though by no means definitive, include drowsiness and yawning in class, heads resting in hands, bodies slouched in seats, vacant or distant stares, repeated finger or foot tapping and persistently watching the clock (Wallbott, 1998; D'Mello and Graesser, 2009). Overheard statements like 'watching paint dry', 'as dull as dishwater' and 'bored to tears' offer further, if uncomfortable, clues. Until only recently, however, and despite acknowledgement as a largely negative and deactivating achievement-related emotion known to impact usually adversely on student engagement and performance, the formal study of academic boredom was a largely neglected and underdeveloped field (Schutz and DeCuir, 2002; Schutz and Pekrun, 2007; Linnenbrink-Garcia and Pekrun, 2011). Despite rapid growth in international interest (van Tilberg and Igou, 2012; Vogel-Walcutt et al., 2012; Goetz et al., 2014; Mercer-Lynn et al., 2014; Pekrun et al., 2014; Vodanovich and Watt, 2016), with attention turning more and more to the 
overall emotional development and well-being of undergraduates themselves (Illeris, 2003; Christie et al., 2008; Kahu et al., 2015; Asikainen et al., 2017; Hagenauer et al., 2017; Loon and Bell, 2017), UK research is only now beginning to respond (Mann and Robinson, 2009; Sharp et al., 2016, 2017a,b, 2018). While the study of academic boredom has certainly been impeded because of the many and complexly inter-related social and psychological processes involved, the (mis)attribution of all manner of things to boredom and vice versa has also rendered it traditionally difficult to isolate and explore (Pekrun, 2000, 2006; Pekrun and Stevens, 2010).

At one level, of course, it might be assumed that academic boredom is nothing to be overly concerned about. While certainly not immune to its effects, and easily shrugged off as a minor distraction by some, academic boredom can, in fact, be a positive and creative experience providing opportunities for self-reflection and the generation of new ideas, as well as fostering resiliency and relationships (Harris, 2000; Pekrun et al., 2002a; Vodanovich, 2003a; Goetz et al., 2010; Villavicencio and Bernardo, 2013; Mann and Cadman, 2014). Academic boredom may also be a force for good by making it known that a search for variety is required, if only to offer protection from the discomfort and frustration of feeling bored itself (Bench and Lench, 2013, 2018; Willis, 2014; Elpidorou, 2017). For the majority, however, academic boredom is now known to play a more critical role than previously imagined. According to Trowler (2010):

'... student engagement is concerned with the interaction between time, effort and other relevant resources invested both by students and their institutions intended to optimise the student experience and enhance the learning outcomes and development of students and the performance and reputation of the institution ...'(2)

With $26 \%$ to $59 \%$ of undergraduates in different studies claiming to get bored in lectures alone, the immediate and cumulative effects of academic boredom are anything but trivial.

\section{Aims and scope}

This article aims to provide a review and synthesis of relevant literature surrounding the academic boredom experienced by undergraduates at university. It does this by 
first considering how boredom as a phenomenon has been conceptualised, located theoretically, defined and investigated somewhat generally, taking in boredom proneness and the study of boredom as a trait. It then moves on to consider academic boredom more specifically, including its sites and triggers, how undergraduates respond and cope and the implications and limitations arising from findings. In a sector increasingly exercised by teaching excellence, student satisfaction, retention and value for money, it does this through the eyes of educationalists rather than psychologists, psychology having tended to dominate the field, and in the spirit of introducing academic boredom to a wider audience with a resource to help stimulate further educational and interdisciplinary research (Davies, 2000). The literature here was initially identified from a key word search of educational and psychological databases including Google Scholar, ERIC, psychINFO and psychArticles, backsearching through reference lists and our own familiarity with the field (see endnote). This was subsequently filtered and reduced to admit only those peer-reviewed and refereed journal articles and academic texts written in English and readily available in the public domain. From the reading of abstracts and larger sections of text in the first instance, 287 individual items met the basic requirements for inclusion, 179 with boredom actually in the title and 86 involving sample groups of undergraduate students themselves.

\section{Scant and sporadic attention}

\section{The early years}

In the thought provoking 'Boredom: A lively history', Toohey (2012) informs us that despite having been felt for an eternity, terms such as 'bore', 'boring' and 'bored' made their first appearance in the English language in personal letters and other surviving documents between 1766 and 1778 and again in print in the 1852 novel 'Bleak House' by Charles Dickens (related terms such as 'ennui' and 'langeweile' were in more widespread use earlier in France and Germany while 'acedia' can be traced back to the ancient Greeks). Despite a long-standing cultural interest ever since (Healy, 1986; Spacks, 1995; Haladyn, 2015), including consideration from philosophers such as Kierkegaard and Heidegger (Svendsen, 2005), however, boredom received relatively little formal or systematic attention until later (McDowell and Wells, 1927; Barmack, 
1937; Lewinsky, 1943; Fenichel, 1951; Heron, 1957; Fiske and Maddi, 1961; Geiwitz, 1966; O’Connor, 1967). Nevertheless, boredom was usefully described by Barmack (1938) as:

'... a state of conflict between the tendency to continue and the tendency to get away from a situation which has become unpleasant principally because of inadequate motivation resulting in inadequate physiological adjustment to it ...' (125-126)

Acknowledged as easier to describe than to define, the uniqueness of boredom as a phenomenon was also described by Greenson (1953) as:

'... a state of dissatisfaction and disinclination to action; a state of longing and the inability to designate what is longed for; a sense of emptiness; a passive, expectant attitude with the hope that the external world will supply the satisfaction; [and] a distorted sense of time in which time seems to stand still $\ldots$ '. (7)

Greenson's notion of boredom as a multi-dimensional construct involving conflict between the internal and external worlds inhabited by individuals would be revisited many times over in discussion.

Picking up the pace

Growing interest in the study of boredom throughout the 1970s led psychologists in the main to links with low levels of stimulation and sustained attention (London et al., 1972; Thackray et al., 1974; Csikszentmihalyi, 1975; Hill, 1975; Bailey et al., 1976; Abramson and Stinson, 1977; Schubert, 1978). The 1970s also witnessed development of the first questionnaire-based self-report instruments with which boredom could be easily measured and reported (Grubb, 1975). The Zuckerman Sensation Seeking Scale, incorporating a 10-item boredom susceptibility subscale (ZBS), was of particular importance (Zuckerman, 1979). Considered a component of personality, Zuckerman referred to boredom as: 
'... an aversion for repetitive experience of any kind, routine work, or dull and boring people and extreme restlessness under conditions when escaping from constancy is impossible ...' (103)

Not only did the study of boredom and boredom susceptibility become instantly more accessible, the use of questionnaires attracted more quantitative than qualitative appeal. By the end of the 1970s, boredom was established as an unpleasant, transient, aversive and sometimes debilitating state with consequences (Smith, 1981). Less about not having anything to do per se, boredom was more about not having anything interesting or particularly motivating to do from which any meaning or lasting satisfaction could be derived.

\section{An increasingly psychological endeavour}

Models, theories and definitions

Mainstream psychological interest in boredom escalated into the 1980s with attempts to provisionally model it as an emotional construct, to locate it theoretically and to provide an adequate definition. According to Russell (1980), the structure of many different emotions including boredom could be represented diagrammatically in terms of arousal (sleepiness-alertness) and outcome direction or valence (pleasuredispleasure). In the so-called 'circumplex model of affect' presented, Russell was among the first to offer a specific classification of emotions like boredom as well as a means of differentiating between them. Adopting an empirically grounded theory of arousal incorporating elements of habituation and effort, O'Hanlon (1981: 54) reiterated and extended the findings of others by noting that:

- boredom occurred as a reaction to tasks and task situations in which the pattern of sensory stimulation was nearly constant or highly repetitive and monotonous;

- the degree of boredom reported by different individuals working on the same task could vary enormously;

- boredom could occur within minutes of starting a task, particularly if familiar or frequently experienced in the past; 
- the state of boredom experienced by individuals was immediately reversible if the tasks or task situations could be altered or changed.

O'Hanlon (1981) also defined boredom as:

'... a unique psychophysiological state possessing interrelated and inseparable emotional, motivational, perceptual and cognitive concomitants ... a prevalent and sometimes very serious problem in real-life situations ...' $(53,76)$

Perkins and Hill (1985) similarly regarded boredom 'a state of subjective monotony' (231) resulting in high levels of frustration alongside low levels of interest and concentration (see also Hill and Perkins, 1985). Modelling its cognitive as well as affective dimensions, involving a theoretical framework based on attention in addition to arousal, Perkins and Hill considered the evidence to support boredom's physiological changes less convincing. While Leary et al. (1986) were quick to point out the persistence of descriptions in terms of [boredom's] situational antecedents, physiological correlates, phenomenological concomitants and behavioural consequences' (968), psychologists also turned their attention to the boredom-related social and psychological problems in the real-life situations alluded to by O'Hanlon and what could be done to alleviate their effects (Thackray, 1981; Drory, 1982; Hamilton et al., 1984; Orcutt, 1984; Lee, 1986; De Chenne, 1988; Damrad-Frye and Laird, 1989; Ganley, 1989). This extended to how television viewing and the selection of which programmes to watch over others might help (Bryant and Zillman, 1984).

\section{Convenient participants}

With ease of access to groups of readily available and willing participants, the study of boredom in the 1980s also progressed to using opportunity or convenience samples of mostly undergraduate psychology students themselves (Wolfgang and Dowling, 1981; Titley and Titley, 1982; Wright and Moore, 1982; Ratcliffe and Burkhart, 1984; Johnston and O'Malley, 1986; Tolor, 1989). Pursuing the engagement and achievement of a more mixed-discipline sample group of 223 students attending college in the United States, however, Maroldo (1986) reported the first slight but negative and significant correlation between boredom and grade point average (GPA) 
albeit among the 122 male participants only (mean age 20.4 years, $r=-.18, p<.05$ ). Details of the 'College Student Boredom Scale' (396) used were not provided. Similarly, and from a questionnaire survey of 252 first years enrolled on at least one 'remedial course' (43) at another college in the United States (no mean age provided), Aldridge and DeLucia (1989) noted $41 \%$ feeling frequently bored as a result of the mismatch between course expectation and reality, with $80 \%$ indicating a need for more classroom stimulation. Introducing the term 'academic boredom' perhaps for the first time, Aldridge and DeLucia also referred to its presence as an 'academic plague' (43).

Boredom proneness and the Boredom Proneness Scale (BPS)

Recognising boredom as a 'common emotion', and noting the 'disparity between the importance of boredom as an issue in psychology, education and industry and the dearth of research that addresses this disposition' (4), Farmer and Sundberg (1986) considered boredom a trait as well as a state. Despite validation with a sample group of only 233 college undergraduates in the United States (though not as rigorously as might be attempted today), and constructed to measure the recurring propensity or habitual disposition of individuals towards getting bored rather than the actual experience of boredom itself, Farmer and Sundberg's 28-item Boredom Proneness Scale (BPS) became the first full-scale instrument for the assessment of trait boredom among the general population. The overall influence of the BPS on shaping the nature and subsequent direction of the field was immense (Vodanovich, 2003b). Careful scrutiny of the BPS's psychometric properties have since revealed a more involved factor structure, not only in the United States where it was first developed (Vodanovich and Kass, 1990a; Vodanovich et al., 1997, 2005; Melton and Schulenberg, 2009), but also in Canada (Ahmed, 1990), Australia (Gordon et al., 1997), France (Gana and Akremi, 1998), Turkey (Dursun and Tezer, 2013) and Italy (Craparo et al., 2013). While never perfectly replicated, pointing to culture-specific as well as methodological issues in how replication was attempted, some overlap between outcomes is certainly evident (Table 1). Despite its age and psychometric limitations, with many original items now looking somewhat dated in particular, the BPS remains very much in use today (Vodanovich and Watt, 2016).

\section{[Insert Table 1 as close to here as possible.]}


Interestingly, Farmer and Sundberg also asked an independent sample of 63 students to list which topics covered in the course of their day were the most boring, where they directed their attention in class and how they rated their lecturers at the end of sessions themselves. As anticipated, those students more prone to boredom than others were also the most negative in their views. From within their study as a whole, no significant relationships were observed between boredom proneness and course grade or gender, despite male participants scoring more highly than female. While correlation between the BPS and Zuckerman's ZBS was considered satisfactory $(r=.25, p<.01)$, Farmer and Sundberg also realised that these measured different facets of the same thing (the BPS more negative emotionality and withdrawal from the world, the ZBS more sensation seeking emphasising a need for stimulation from external events). As cautioned by Mercer-Lynn et al. (2011), and from a direct comparison of the BPS and ZBS alongside other outcome variables, attempting to draw comparisons between different studies employing different boredom scales, or even different variations of the same scale, can be a hazardous activity.

\section{Characteristics and correlates}

\section{Health-related conditions and pathologies}

With new and different types of boredom emerging over time (existential, job-related, free-time, leisure, marital and sexual), the construction of questionnaire-type, selfreport instruments other than the BPS continued well into the 1990s and beyond (IsoAhola and Weissinger, 1990; Watt and Ewing, 1996; Ragheb and Merydith, 2001; Passik et al., 2003). While the search for theories and definitions remained somewhat problematic (Mikulas and Vodanovich, 1993), research was operationalised from descriptions of boredom alone and drew on what was already known:

'... [boredom] an unpleasant, transient, affective state in which the individual feels a pervasive lack of interest in and difficulty concentrating on the current activity ...' (Fisher, 1993: 396) 
The 1990s also witnessed the emergence of important collaborations between authors with the prolific output from Stephen Vodanovich, Steven Kass and John Watt in the United States worthy of particular mention. While mostly correlational in nature, and largely as a result of the BPS, boredom proneness became statistically associated with a much broader range of factors than ever before. Causal relationships between variables were much less clear (Neu, 1998; Todman, 2003). Adopting the categories provided by Vodanovich and Watt (2016), much of this work can be loosely summarised as follows:

- negative affect including anxiety and depression, loneliness and withdrawal, neuroticism, stress, irritability, hostility and anger, disruption and aggression, alexithymia and somatic disorders (Vodanovich et al., 1991; Watt and Vodanovich, 1992; Rupp and Vodanovich, 1997; see also Sommers and Vodanovich, 2000; Eastwood et al., 2007; Goldberg et al., 2011; Merrifield and Danckert, 2014);

- attention deficit and cognitive disorders including lapses in memory, the altered perception of time, self-actualisation and procrastination (McLeod and Vodanovich, 1991; Watt, 1991; Watt and Blanchard, 1994; Blunt and Pychyl, 1998; Seib and Vodanovich, 1998; see also Kass et al., 2001b; Wallace et al., 2003; Danckert and Allman, 2009; Malkovsky et al., 2012);

- personality variables including extraversion, introspection, peer and personal relationship problems and narcissism (Vodanovich and Kass, 1990b; Polly et al., 1993; Wink and Donahue,1997; Watt and Vodanovich, 1999; see also Gana et al., 2000; Zondag, 2013);

- impulse control deficits including gambling, smoking, alcohol and substance abuse, eating disorders, sexual promiscuity, dangerous driving and self-harm (Kass and Vodanovich, 1990; Stikney and Miltenberger, 1999; see also Dahlen et al., 2004, 2005; Kass et al., 2010; Mercer and Eastwood, 2010; LePera, 2011; Hodgkins and Racicot, 2013; Moynihan et al., 2015).

With undergraduate psychology students remaining in the front line as willing participants, domain-specific attention was often directed more towards the potential for clinical diagnosis, providing therapeutic help and offering counselling services than 
engagement and achievement per se. By way of illustration, Watt and Vodanovich (1999) investigated boredom proneness and the psychosocial development of 142 student volunteers at a college in the United States (mean age 19.4 years). With psychosocial development presented as how traditional-aged college students resolve biological and psychological changes within themselves in relation to environmental experiences and expectations' (303), boredom proneness correlated negatively with the range of academic and non-academic indicator variables considered including educational involvement, career and lifestyle planning, cultural participation, tolerance and emotional autonomy $(r=-.24$ to $-.54, p<.001$ in all instances). Despite a valuable and informative discussion of gender differences and how boredom might actually be alleviated from within, the opportunity to design and introduce more effective courses received only minor mention.

\section{Against the tide}

Pre-occupied with the construction and psychometric properties of questionnaires and the search for individual differences in personal psychology (Piotrowski, 2013), the study of boredom and boredom proneness also had its critics. In additional collaborations of note, Eastwood et al. (2012) considered the study of boredom still a 'relatively obscure niche' (483) not all of which could be captured using questionnaires. Similarly, Fahlman et al. (2013) pointed out that while trait and state boredom might appear somewhat similar, they were, in fact, psychologically quite distinct, with measures of trait boredom failing to consider the strength and frequency with which boredom occurs at all (and therefore not a proxy). Mercer-Lynn et al. (2013) also wondered if trait actually considered individuals more pre-disposed to boredom than others or people who simply reacted more to boring situations. Further, and according to Vogel-Walcutt et al. (2012), the focus on self-report instruments like the BPS also overwhelmed alternative methods of assessment including computer-assisted observation (used to monitor dialogue, facial expression and body posture) and physiological testing (using electroencephalography, galvanic skin responses and eye tracking technology). Adopting interviews over questionnaires, studies from within sociology, social psychology and other related disciplines offered more qualitative and quite different perspectives across other areas of interest (Brisset and Snow, 1993; Phillips, 1993; Wienstein et al., 1995; Darden and Marks, 1999; Barbalet, 1999; 
Binnema, 2004; Ferrell, 2004; Fahlman et al., 2009; Todman, 2013; Mercer-Lynn et al., 2014; van Tilberg and Igou, 2011, 2016). These focused mainly, though not exclusively, on existential boredom and the notion that life has no meaning other than that ascribed to it and socially validated. In the work of Martin et al. (2006) in one area of the UK, for example, 20 interviews with 10 participants aged 18 to 81 recruited through adverts placed in the local newspaper, a job centre, a residential home and places of work identified a small range of antecedents associated with boredom including repetitive lifestyles, a lack of social stimulation, isolation from others, poor time management and little disposable income. Those considered more frequently bored than others often felt trapped and restless yet lethargic, while those less frequently bored espoused a positive philosophy about life, maintained a good sense of humour and had many interests and hobbies to keep them occupied. Strong spiritual connections also featured prominently (see also van Tilberg et al., 2018). In a single study of 296 undergraduates aged 17 to 48 in the United States, the relationship between spirituality and boredom proved more involved, while a negative relationship between boredom and the meaning and purpose in life was clearer (MacDonald and Holland, 2002). Elsewhere, and attending to existential boredom in the extreme, being 'bored to death' sometimes took on more literal than metaphorical meaning (Maltsberger, 2000; Britton and Shipley, 2010).

\section{A troubled field}

As well as facing increasing criticism, the new millennium also ushered in moves towards unravelling and clarifying some of the uncertainties and contradictions of the past. Returning to Eastwood et al. (2012), conventional theories of boredom fell into four overlapping camps:

- psychodynamic - repression and the perceived threat of fulfilling a desire to mentally engage with something meaningful;

- existential - the sense of emptiness or lack of life meaning resulting in paralysis of agency or giving up;

- arousal-related - the non-optimal mismatch between the need for stimulation and its availability; 
- attention-related - failures in cognitive processes which require effort and result in an inability to concentrate.

With theories of arousal and attention receiving most credibility among psychologists, being the most widely understood within their domain, as well as giving rise to hypotheses with testable predictions, definitions alluding to boredom's underlying mental processes followed suite. According to Fahlman et al. (2013), for example:

'... boredom is the aversive experience of having an unfulfilled desire to be engaged in satisfying activity. In terms of arousal, the bored individual experiences either agitated high arousal and/or lethargic low arousal. Cognitively, the bored individual experiences a slow passage of time and an inability to focus his or her attention ...' (71)

Following on, Fahlman et al. (2013) also introduced the Multidimensional State Boredom Scale (MSBS), the first psychometrically evaluated self-report instrument of its type to rival the BPS. In stark contrast to the BPS, though with similar limitations in terms of its representativeness, however, this was validated in several stages with over 2000 students at two universities in Canada (mean ages at each stage 19.6 to 21.2 years) and achieved using exploratory and confirmatory factor analysis (see also Liu et al., 2013; Song et al., 2013; Alda et al., 2015; Ng et al., 2015). The study of boredom as a whole, including academic boredom such as it was, had reached something of an impasse.

\section{Academic boredom comes of age}

With the term 'academic boredom' first used in the 1980s, it took until the new millennium to fully come of age. Retaining the use of modified versions of the BPS within their methodologies, and published without knowledge of the paradigm shift already on the horizon in the form of Control-Value Theory (CVT), two articles bucked the trend of previous decades by adopting a more educational lens and looked at the wider impact of academic boredom on being a student more broadly. Both merit further mention.

Phenomenology 
In perhaps the most frequently overlooked study of its time, Mary Harris (2000) at the University of New Mexico considered the relationship between academic boredom and mood among 170 undergraduate as well as graduate students studying education in the United States (mean age 28.0 years). Importantly, Harris's four page questionnaire also collected information on some of the more phenomenological aspects of boredom affecting participants more generally. As predicted, boredom proneness and the ability of individuals to monitor their own moods correlated positively $(r=.18, p<.05)$ while their ability to identify and label their own moods correlated negatively $(r=-.33, p<.01)$. A negative correlation was also observed with flow and the optimal balance between environmental challenge and skill $(r=-.30$, $\mathrm{p}<.01$ ). In addition, however, Harris also reported that $10 \%$ of participants claimed never to get bored at all, while the rest admitted to getting bored at least once or twice a day. The commonest descriptions associated with feeling bored included restlessness and tiredness (up to $26 \%$ of participants), with lectures, having nothing to do, a lack of challenge, loneliness and waiting around among the most commonly cited triggers (up to $35 \%$ of participants). Coping strategies included reading, daydreaming, socialising, watching television and participating in physical activity. In terms of their educational experience, Harris suggested that:

'... we faculty members who wish to avoid boring others might note that lectures/classes and lack of something to do are the most frequent causes of boredom. This information could certainly be viewed as an incentive to change our teaching styles to the kind of learner-centred, active model that educators recommend ...'(595)

Many participants also considered boredom a positive experience by providing space for thought. The notion of academic boredom impacting on the leisure time and nonacademic activity of students was subsequently expanded upon by Barnett and Klitzing (2006) from a questionnaire survey of 999 undergraduates attending three large mid-western universities also in the United States (mean age 20.8 years). Grouping participants by demographic characteristics, personality, motivational orientation and affective style, those displaying greater emotional stability, an ability to entertain themselves and fill their free time in an enjoyable way and extroverts also presented with lower levels of perceived boredom than others. Barnett and Klitzing 
tentatively suggested that leisure education programs at university should be expanded upon and customised to better match expectations.

\section{Boredom in the lecture theatre}

Adopting a broadly similar approach, Sandi Mann and Andrew Robinson (2009) at the University of Central Lancashire considered academic boredom and the educational experiences of 211 undergraduates recruited at random from general areas of the campus at a university in the UK (no mean age provided). On the whole, noninteractive and transmission-led methods of course delivery like lectures were considered more boring than participatory methods including seminars, working in groups and practicals. Lectures using PowerPoint presentations without handouts and requiring the students to copy notes attracted particular criticism (see Bartsch and Cobern, 2003, and Kinchin et al., 2008, for further discussion). Findings suggested that $29 \%$ of participants found lectures boring at least half of the time, $27 \%$ most of the time and $3 \%$ all of the time. Coping strategies included daydreaming, doodling, simply switching off, talking to a neighbour, texting a friend, leaving during a break or playing games on mobile phones. Laboratory and computer-based sessions were actually the least well received, a feature thought due to the predictability of intended learning outcomes. In all aspects considered, those more prone to academic boredom than others were among the worst affected (correlation with missing class $r=.18, p<.01$ ). In common but with a twist on Harris (2000), Mann and Robinson concluded that:

'... this study has implications for future research which could be usefully directed at examining the relationship between student boredom, boredom proneness and actual grades achieved at university ... [or] ... on drop-out rates ... Lecturers should not assume that "interactive" teaching methods ... are automatically more engaging ... [as] ... these ... can be even more boring ...' (256)

Mann and Robinson's work is also notable for its publication in an educational rather than psychological research journal.

\section{Contemporary perspectives}


A major breakthrough in the study of academic boredom, engagement and achievement came with the introduction of Control-Value Theory (CVT) and the ground-breaking research led by Pekrun $(2000,2006)$. Alongside recognition that most undergraduates commonly experienced a small number of achievement-related emotions during the course of their work (boredom, anger, hopelessness, shame, anxiety, enjoyment, hope, pride and relief), CVT integrated many of the assumptions embedded within other related theories thereby offering a more fruitful and transtheoretical framework which better acknowledged the complexity and hybridity of academic boredom across a range of sometimes diverse educational settings (Pekrun, 1984, 1992a,b; Weiner, 1985; Perry, 1991; Bandura, 1993; Schönwetter et al., 1993; Pekrun and Stevens, 2010). Drawing on the dynamic systems component model presented by Scherer (2000, 2005 and later 2009), as well as the earlier contributions of others, Pekrun considered academic boredom a psychological subsystem with affective, cognitive, motivational, expressive and physiological processes working together in coordinated ways. Pekrun went on to consider all commonly experienced achievement-related emotions linked directly to both achievement activities and achievement outcomes, the latter being anticipatory or retrospective in nature. Pekrun also noted that achievement-related emotions could still be considered trait-like and 'habitual' or state-like and the 'momentary occurrences within a given situation at a specific point in time' (2006: 317). Importantly, and with CVT predicting the outcome direction or valence (positive or negative) as well as the nature of response itself (activating or deactivating), all commonly experienced achievement-related emotions were grouped around their main effect:

- negative and deactivating (boredom and hopelessness)

- negative and activating (anxiety, anger and shame)

- positive and activating (enjoyment, hope and pride)

- positive and deactivating (relief)

Consistent with CVT, academic boredom was subsequently (re)defined after O'Hanlon (1981) as a psycho-physiological response to a supposedly meaningful educational 
event and no longer the invisible or 'silent emotion' unworthy of attention (Pekrun et al., 2010: 531). The basic premise of CVT, that an individual's appraisal of control and value with respect to achievement activities and outcomes might radically influence student engagement and achievement was game changing. CVT provided the conceptual understanding of achievement-related emotions like academic boredom and their wider relationship with learning from which subsequent investigations could be better operationalised (see also Perry et al., 2001; Artino et al., 2012; Daniels and Stupnisky, 2012; and Roick and Ringeisen, 2017).

CVT also brought with it the development of new questionnaires (Table 2). In only the few years between reviews (Vodanovich, 2003b; Vodanovich and Watt, 2016), the number of research instruments with which to measure boredom not only increased from eight to sixteen, five of the new additions were dedicated to academic boredom alone: the Achievement Emotions Questionnaire (AEQ), the Learning-Related Boredom Scale (LRBS), the Boredom Coping Scale (BCS), the English Precursors to Boredom Scale (E-PBS) and the Academic Boredom Scale (ABS-10). Other instruments also available include the Student Experience of Emotions Inventory (SEEI) and a revision of the BPS developed specifically for use in the UK (BPS-UKHE). With new research teams led by or including Reinhard Pekrun at the University of Munich himself, Virginia Tze at the University of Alberta and others working more independently, the study of academic boredom among undergraduates flourished. Unfortunately, and for the most part, so too did the technical level of detail in reporting demanding some proficiency with the language and professional discourse of psychologists and a moderate to high level of statistical literacy.

\section{[Insert Table 2 as close to here as possible.]}

\section{Academic boredom and the Achievement Emotions Questionnaire (AEQ)}

Following completion of a programme of both qualitative and quantitative research intimately associated with the introduction of CVT, Pekrun et al. (2002b) reported the AEQ constructed and initially validated, in part at least, from a sample of 230 undergraduate psychology students in Germany (no mean age provided). With all commonly experienced achievement-related emotions variously represented across 
class-related, learning-related and test-related settings (boredom, anger, hopelessness, shame, anxiety, enjoyment, hope, pride and relief), both trait and state forms were available depending on the wording of instructions. With up to 361 individual items in total, the $A E Q$ was large. In addition to its initial construction, Pekrun et al. (2002b) also provided a review of findings arising from seven crosssectional, three longitudinal and one diary study using the AEQ alongside other questionnaires. From the original sample of 230 students mentioned previously, academic boredom correlated negatively with intrinsic motivation to learn $(r=-.63$, $\mathrm{p}<.001)$, perceived effort $(\mathrm{r}=-.50, \mathrm{p}<.001)$, the adoption of certain learning strategies over others (elaboration $r=-.26, p<.001$ ) and the ability of participants to manage their own level of engagement through self-regulation $(r=-.21, p<.01)$. Academic boredom also correlated positively with irrelevant thinking $(r=.72, p<.001)$. Though full details were omitted, achievement-related emotions measured early over the course of the study predicted cumulative as well as final examination grades with regression coefficients higher for boredom than for other more activating emotions (further details in Pekrun et al., 2009).

With an AEQ user's manual in the public domain (Pekrun et al., 2005a), other studies quickly followed including the work of Daniels et al. (2008, 2009), Tanaka and Murayama (2014) and Ranellucci et al. (2015) on competence-relevant achievement goals (task mastery, performance-approach and performance-avoidance), Garn et al. (2017) on belongingness and the work of Artino (2009-2012), Baker et al. (2010) and Heckel and Ringeisen (2017) in online learning. Academic boredom was found to impact adversely on almost all variables considered, with the notable exception of students working in groups or teams on real-life practical tasks and simulations (Noteborn et al., 2012). Interestingly, and from the work of Ruthig et al. (2008) with 620 students taking an introductory psychology course in the United States (mean age 18.0 years), lower levels of boredom proneness predicted significantly better overall grades and less class-cutting among those students with higher levels of perceived control than others, while the benefits of control were effectively nullified when boredom proneness was high. Similarly, and from the work of Respondek et al. (2017) with 883 psychology, science, computing, engineering, mathematics and economics students in Germany (mean age 20.2 years overall), drop-out intention as a result of academic boredom was actually highest among the second years involved rather than 
the first years as had been anticipated and thought due, in part, to novelty, enjoyment, goal orientation and the lack of failure experiences promoting higher levels of perceived control and protection (see also Barefoot, 2004). The authors also noted that the research was undertaken ahead of the first formal examination period.

Being the first and most important scale of its type, different versions of the AEQ have since been adapted for use across the full educational spectrum (Pekrun et al., 2005b; Govaerts and Grégoire, 2008; Lichtenfeld et al., 2012; Peixoto et al., 2015; Hong et al., 2016). Despite its widespread availability, however, a complete psychometric evaluation of the AEQ was not published until well after it first appeared (Pekrun et al., 2011) and with a sample group of 389 students taking undergraduate psychology courses across a range of disciplines in Canada (mean age 20.6 years). Concerns surrounding version control and the translation and back-translation of individual questionnaire items from German into other languages remain.

\section{Learning-related academic boredom}

With academic boredom firmly identified as an important and largely negative and deactivating achievement-related emotion of importance, the AEQ's Learning-Related Boredom Scale (LRBS) was eventually extracted and used alone. In a series of interrelated investigations overlapping with and extending their earlier work, Pekrun et al. (2010) considered further the control-value appraisals associated with academic boredom in both trait and state forms. Working with individual sample groups of between 122 and 389 undergraduate psychology and education students again in Germany and Canada (mean ages of 19.7 to 24.0 years), at least one of which had also featured in the validation of the $A E Q$, academic boredom continued to correlate with the range of other variables included as anticipated (intrinsic motivation $r=-.26$ to $-.61, p<.01$; perceived effort $r=-.45$ to $-.51, p<.01$; self-regulation $r=-.22$ to $-.28, p<.05$; attention deficit $r=.65$ to $.77, p<.01$ ). With major findings appearing broadly consistent across the two different cultural contexts, structural equation modelling also demonstrated control-value appraisals predicting academic boredom and academic boredom predicting academic performance. In a later study of 424 undergraduates taking an introductory psychology course in Canada alone (mean age 20.5 years), Pekrun et al. (2014) employed a small number of particularly advanced structural 
equation models to test the reciprocal rather than linear relationship between academic boredom and achievement over an entire semester and a more likely causeeffect scenario. Controlling for gender, age, interest, intrinsic motivation and prior achievement at school, academic boredom was found to exert a negative influence on subsequent academic performance and vice versa as predicted (correlations between academic boredom and course grade over the different assessment periods involved ranged from $r=-.22$ to $-.36, p<.01)$.

As with the AEQ, a complete psychometric evaluation of the LRBS as a stand-alone instrument was published after its initial use by Tze et al. (2013a) who also established its utility in Western as well as non-Western cultures from sample groups of students studying education in Canada (mean age 23.3 years) and in China (mean age 21.0 years). Tze et al. (2014b) later established that while control-value appraisals were indeed proximal factors influencing academic boredom, engagement with the teaching-learning environment was equally important if more distal, particularly if few course options or choices were available and support for learning autonomy was lacking. In the complex analysis of engagement alone, academic boredom correlated often strongly with vigour $(r=-.64, p<.01)$, dedication $(r=-.65, p<.01)$, absorption $(r=-$ $.63, p<.01)$ and effort regulation $(r=-.42, p<.01)$.

\section{Academic boredom, coping and challenge}

Partly alongside validation of the LRBS, and in common with the rest of their work involving sample groups of undergraduate students in Canada and China, Tze et al. (2013b, 2014a) also revisited the Boredom Coping Scale (BCS) and an English version of the Precursors to Boredom Scale (E-PBS) originally published for use in German schools (Nett et al., 2010, 2011; Daschmann et al., 2011; see also Daniels et al., 2015). Consistent with CVT, the strategies identified for coping with academic boredom included a cognitive-approach (aimed at identifying value in finding meaning in learning), cognitive-avoidance, a behavioural-approach (aimed at increasing subjective control in learning situations) and behavioural-avoidance. These were often adopted in combination resulting in three qualitatively different types of respondent: reappraisers (cognitive-approach dominant), criticisers (behavioural-approach dominant) and evaders (both cognitive and behavioural avoidance dominant). Based 
on the premise that basic strategies associated with coping should be broadly similar, but that different cultural values and norms might have an impact on shaping emotional experiences, participants in Canada were reported as reappraisers while participants in China were reported as evaders and considered less likely to challenge the authority of their lecturers (see also Zhou and Kam, 2017). No appreciable correlations were observed with GPA, but the GPA measure available was considered insufficiently sensitive to produce a reliable result. In the case of the E-PBS, the most significant precursors of academic boredom included over-challenge $(r=.15, p<.05)$, monotony as a result of familiar routine $(r=.22, p<.01)$, lack of meaning in learning $(r=.22, p<.01)$ and the opportunity cost of having better things to do $(r=.34, p<.01)$. Academic boredom also correlated negatively with self-efficacy for self-regulated learning ( $r=-$ $.36, p<.01)$. The involvement of over-challenge confirmed earlier findings reported by Acee et al. (2010) during development of the Academic Boredom Scale (ABS-10) in the United States, bringing to an end the commonly held belief that academic boredom arose solely from being under-challenged alone.

Motivation, strategies for learning and achievement: A meta-analysis

With growing interest in the relationship between academic boredom, the different strategies adopted by students when learning and achievement in particular, Tze et al. (2016) provided a comprehensive summary of the field in a meta-analysis of 29 studies involving 19,052 participants published between 1990 and 2014 from which correlation coefficients were available and effect sizes could also be determined. While the exact nature and number of reported variables, as well as the methodologies and instruments involved in data collection, often proved inconsistent, findings indicated a negative but meaningful association in all instances, with low to moderate

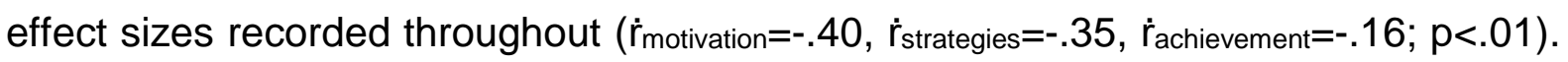
In addition, the effect of academic boredom experienced in class-related situations ( $\left.\dot{r}_{\text {class }}=-.35\right)$ was also found to be greater than when studying ( $\left.\dot{r}_{\text {study }}=-.25\right)$. The detrimental influence of academic boredom observed overall was considered a function of repeated control and value appraisals arising from a series of reciprocal and mediated events occurring over time and consistent with CVT. Despite rigour in the selection of suitable publications and the robustness of the analysis throughout, however, only 22 of the 29 studies involved dealt with undergraduate participants 
alone (the others focusing on pupils in schools) and only 18 of those appeared as peer-reviewed or refereed articles in journals (the others being unpublished doctoral theses and reports). Nevertheless, the overall effect of academic boredom on motivation, adopted learning strategies and achievement in combination remained significant (ن்ndergraduate=-.23, p<.001). In terms of achievement as a single variable of interest, however, only 13 studies provided data considered suitable for purpose, with achievement variously reported as GPA, test results, test performance, examination scores and final course grades, not all of which, as noted earlier, are sufficiently sensitive to produce reliable results. With the range of individual correlation coefficients and effect sizes for achievement understandably broad as a result, a detailed understanding of cultural and situational context is of critical importance (Table 3). Interestingly, and from an earlier structural equation model of questionnaire data obtained from 5,805 undergraduates sampled across all disciplines and year groups at the University of Padua in Italy (mean age 22.5 years), Mega et al. (2014) also reported the mediated effects of emotions like academic boredom on achievement, with motivation and self-regulation playing a prominent role. According to Perry et al. (2001), those students more focused on success at university not only tend to report less boredom than others, they often feel more in control of their lives in general and believe they perform better academically.

\section{A typology of states}

Adopting a somewhat different research design and methodological direction from others in the field, Goetz et al. (2014) applied their earlier work on in vivo sampling and the latent profile analysis of boredom in schools in order to investigate the nature of academic state boredom among students at university (see also Goetz et al., 2010). Resonating with the earlier work of Russell (1980) and others, this was based on the assumption that academic boredom as a state should manifest itself as different entities associated with increasingly higher levels of arousal (e.g. a calm or fidgety disposition) alongside similarly increasing levels of negative valence (e.g. unpleasantness). 63 undergraduates studying psychology, education, law, physics, literature, politics and sport in Germany (mean age 24.1 years) were asked to respond to a number of randomised signals from a personal digital assistant at different times of the day over a two-week period. After prompting, they were then required to 
complete a digital questionnaire about their activities and experiences of boredom either immediately or as soon as possible thereafter. In total, five different state variations were identified from which a boredom typology was established:

- indifferent boredom (lowest level of arousal, positive or slight negative valence - the least unpleasant, individuals may appear relaxed, withdrawn or indifferent, thought least likely to occur in achievement-related settings);

- calibrating boredom (uneasiness and distraction - individuals receptive to and could but choose not to react to their situation);

- searching boredom (restlessness - individuals respond to their situation by looking for change or alternative stimuli to maintain attention);

- reactant boredom (high level of arousal, high negative valence - the most unpleasant, individuals motivated to leave, frustration, anger or disruptive behaviours);

- apathetic boredom (low level of arousal, high negative valence - especially debilitating, results in learned helplessness, presentation similar to depression).

Findings also demonstrated that individuals tended to consistently exhibit the same state variation over time rather than different variations at random, with personalityspecific and environment-specific factors working together and considered responsible. In the case of indifferent boredom, non-academic activities were thought to afford greater freedom with respect to the choice and duration of activities undertaken with greater opportunities presented to withdraw from anything considered unnecessarily boring.

Academic boredom, approaches to learning and perceptions of the teachinglearning environment

Inspired by the Enhancing Teaching-Learning Environments in Undergraduate Courses Project (ETLP) in the UK (Entwistle et al., 2002; Hounsell and Entwistle, 2005) and the work of Trigwell et al. (2012) in Australia, as well as to replicate and extend the earlier work of Mann and Robinson (2009), our own work in the field (Sharp et al., 2016, 2017a,b, 2018) also broke with tradition by approaching the study of academic boredom as educationalists rather than psychologists and by investigating 
academic trait and state boredom together in an exploratory study of mixed-methods design. Boredom proneness was measured using the BPS-UKHE and circulated within a larger academic boredom survey instrument among final-year Education Studies students at a single university in England. Questionnaires from the ETLP were also used to consider approaches to work as well as course expectations and perceptions of the teaching-learning environment. Individual research interviews undertaken later complemented and informed the quantitative findings. Summarising from within the last reported phase (Sharp et al., 2017b), almost all 179 participants involved (mean age 24.4 years) displayed some propensity towards academic boredom with lower levels of engagement reported in traditional lectures than in other forms of delivery (58.6\% half of the time or less). In addition to a perceived excess and inappropriate use of PowerPoint, other factors triggering the actual onset of academic boredom itself included the personal attributes and qualities of the lecturer, the relevance of lecture material presented, coherency and pace, a lack of studenttutor interaction, student behaviour and the lecture-theatre environment. This was also reflected at interview, with some responses serving to capture the very essence of academic boredom as a whole:

'Sometimes when lecturers have used a lot of PowerPoints and not really interacted with everyone in the lecture theatre it becomes a bit monotonous ... I don't like it when people turn the lights off ... that makes me more sleepy ... The speed of the content that's been covered in the lecture, especially if it's new ... I get completely muddled ... and the rest of the lecture becomes a blur ... you're catching up ... not concentrating, completely lost and panicking a bit ... I generally either doodle or go on social media ... I feel frustrated at myself because I feel like I should be concentrating but then I also feel like "Why am I here?" ... It feels a bit pointless.' (14)

Interestingly, and despite their value as a means of 'escape', for both academic as well as non-academic purposes, the disadvantages of digital distractions associated with academic boredom in class, including social media, mobile phone use and the Internet, are only now beginning to emerge (Pempek et al., 2009; Kalpidou et al., 2011; McCoy, 2013; Lepp et al., 2015; Li et al., 2015; Skues et al., 2016, 2017; Bolkan and Griffin, 2017; Elhai et al., 2017). Academic boredom was also found to occur during the completion of written assignments for the purposes of assessment (duration, familiarity and repetition). Cluster analysis of the quantitative data indicated that those 
participants more prone to academic boredom than others also appeared less intrinsically motivated and more likely to lack a sense of purpose. They were also more likely to describe their attendance at university as good rather than excellent, to manage their time and to deploy other resources less effectively and to spend less time in self-study over the course of a week. With boredom proneness and final year degree mark negatively correlated as anticipated $(r=-.32, p<.001)$, those participants more prone to academic boredom and less engaged than others were also found to graduate with lower class degree awards. Mindful of their mediating, reciprocal and mutually reinforcing relationships, basic path analysis highlighted academic boredom as a positive predictor of surface approaches to learning (path coefficient .49, $p<.001$ ), a negative predictor of organised effort (path coefficient -.40, $p<.001$ ) and a negative predictor of perceived course experiences (path coefficient $-.32, p<.001$ ).

\section{[Insert Table 3 as close to here as possible.]}

\section{A discussion of implications and limitations}

\section{Situations and scenarios}

From the review and synthesis of relevant literature presented, academic boredom appears sufficiently different to other known types of boredom to warrant a unique and important field of study. Regarded now as a negative and deactivating achievementrelated emotion impacting usually adversely on student engagement and overall performance, few appear immune to its effects. The sites, triggers, responses and coping strategies associated with academic boredom are better understood now, however, than at any other time in the past. Defined as the psychophysiological response to a supposedly meaningful educational event, and predicted by ControlValue Theory (CVT), many undergraduates find the familiar and everyday routines associated with being at university overly repetitive and monotonous, reacting sometimes unfavourably as a result. Bearable for the most part as the searching or calibrating boredom described earlier, certain elements of the teaching-learning environment encountered provide greater opportunities for academic boredom than others. 
For those undergraduates more prone to academic boredom than others in particular, and in the confining environment of the lecture theatre with nowhere else to go and little else to do, for example, it may all start with a lack of motivation or interest in the lecture itself. Unaroused and inattentive from the outset, concentration wanes and minds begin to wander. Drowsiness, restlessness or even frustration ensues, with perhaps visible changes in body language and behaviour. With little effort directed towards the task at hand, the ability to self-regulate and re-engage with the lecture is compromised. Increasingly distracted and state- rather than goal-oriented, time 'slows' down and other activities are pursued, if only to stay awake or to avoid any further unpleasantness. While some distractions may actually prove useful and productive, others are not. Related classes are avoided and future lectures missed. Over the course of a single semester or an entire academic year, and experienced as more than just a series of random events, including the boredom associated with studying and preparing assignments for the purposes of assessment or revising for tests and examinations, those affected most and at greater 'risk' of falling behind may go on to drop out of university altogether and potentially harming future career prospects and trajectories (see Altay, 2016, for further discussion involving prospective teachers). Experienced regularly and acutely, academic boredom may also be a symptom, or even a cause, of other more serious health-related conditions or pathologies requiring professional help and attention. Fortunately, the research literature also points towards possible solutions.

\section{Boredom mitigation and emotion-oriented pedagogies}

From the post-millennium studies consistent with CVT in particular, the implications of findings have given rise to a number of overlapping suggestions and strategies for boredom mitigation at university, the majority of which begin with identifying situational context and reflect contemporary views of good academic practice (Entwistle, 2009; Fry et al., 2014; Ashwin, 2015; Weinerman and Kenner, 2016). These might also be extended to incorporate many of the principles and practices associated with alleviating boredom at work and derived from the 'job characteristics model' (skill variety, task identity, task significance, autonomy and feedback) as applied in higher education (Kass et al., 2011). 
In terms of control-value appraisals, general consensus focuses around improving course design, communication and monitoring and evaluating the quality of instruction, with greater consideration directed towards ensuring that all of the different elements involved in teaching and assessment are constructively aligned in order to provide the most stimulating and emotion-oriented learning environments possible. This includes regularly reinforcing course aims and objectives and why some forms of delivery and presentation are favoured over others. Addressing the social climate in lectures and other classes to help nurture and stimulate academic integration and student interaction might be also be facilitated by presenting information in more relevant and meaningful ways with concrete examples linked to prior knowledge and experience. Lecturers should certainly remain mindful of when and how best to introduce, sequence, pace and explain new material particularly in the lecture theatre (requiring flexibility, adaptability and responsiveness), while at the same time considering more innovative and creative uses of PowerPoint as a tool for disseminating information. Useful strategies might include breaking up sessions with productive questions to stimulate discussion, intervening to clarify and reinforce points and providing novelty where appropriate. Increasing available options and choices more generally, while also allowing greater freedom for undergraduates to manage their own learning, albeit with support, is also considered essential.

With further attention directed towards control-value appraisals, lecturers should also remain mindful of the intentions, behavioural adaptations and study habits of undergraduate students towards assessment and examination requirements and how the choices they make can influence different ways of working, not all of which may be productive in helping meet intended learning outcomes. Assessment overlap via coursework deadlines and examination timetables should certainly be avoided where possible, providing opportunity for better quality and more formative 'feedback' to 'feed forward', to increase aspiration and achievement and to spread workload and other demands more effectively and productively, while also understanding that too much completion time, including extensions, can often result in assignment boredom itself. Assessment for learning using transparent marking criteria, as well as providing positive and constructive comments, may also help to manage expectations and avoid any sense of cumulative failure. 
In a similar way, undergraduate students are, unfortunately, not always best placed to recognise their own emotions or the impact that academic boredom and control-value appraisals might have on their work. Frequently attributing successes and failures of the past to successes and failures of the future, resulting in either positive or negative emotional feedback loops, learning developers are ideally positioned to help individuals take increasing academic responsibility for themselves by promoting an awareness of academic boredom and how to deal with it, setting learning goals and targets, reinforcing the benefits of positive rather than negative emotions as a whole and improving resiliency and self-confidence at times of stress which can lower selfesteem and self-worth. Attribution retraining, aimed at increasing metacognitive awareness, motivation, engagement and achievement, while reducing maladaptive ways of thinking and working, has also proved particularly successful (reviews in Ruthig et al., 2004, Haynes et al., 2009, and Patti et al., 2018). Those for whom academic boredom becomes particularly troublesome may also need to be referred to counsellors for the intervention that lecturers and learning developers are not always qualified to provide. Regular meetings with advisory or pastoral tutors, and working collaboratively with others, may also lead to a greater sense of belonging. Undergraduates also need to be made aware that they too have a responsibility to become more involved at university, increasing their own personal enjoyment and satisfaction, and that improvements in academic as well as personal achievement is a shared responsibility. Of course, placing undergraduate students more centre stage may challenge the cultural traditions and pedagogical norms within some disciplines and departments more than others thereby creating a need for staff development.

\section{Limitations and opportunities}

Despite all of the recent international attention, theoretical advances, methodological developments and a growing sophistication in analytical techniques, the study of academic boredom, student engagement and achievement is not without its limitations. At its most basic, and in terms of representativeness, generalisability and portability, the majority of studies considered broadly typical of the field and represented here were undertaken by psychologists with largely opportunity or convenience samples of mostly full-time and often first or second year psychology students attending universities in the United States, Germany, Canada and China, 
sometimes participating for credit (demographic variations and geographical locations, including a greater number of students taking degrees in education and in other subjects, is evident in more recent works). Even then, different authors have often approached their work in different ways and at different levels of abstraction, making direct comparisons more problematic than might normally be expected. As such, programmes of more consistent and inclusive educational and interdisciplinary research across a wider range of age groups and subject disciplines employing experimental, cross-sectional, longitudinal and naturalistic designs are certainly required in order to better capture and reflect the heterogeneity of higher education provision and the nature and diversity of the student population as a whole, as well as to help clarify some of the uncertainties surrounding academic boredom and human behaviour such as it is. This is particularly pertinent if replication across different cultural and situational contexts is required, or the study of academic boredom is to be extended to include other participant groups and the transition into work.

Similarly, the majority of contributions available were also quantitative in nature, with numerical data obtained using different instruments, or different variations of the same instrument, largely in the form of questionnaires, failing, on occasion, to outline the form of academic boredom under investigation (trait, state, class-related, learningrelated, task-related, and so on). The collection and subsequent handling, modelling and interpretation of quantitative data also relies upon a number of assumptions each of which introduces uncertainty. Among those often overlooked include how individual items are translated, received and understood by participants across different cultural and situational contexts, the memory and recall of events sometimes long gone, a reliance on self-reporting, questionnaire fatigue and how ordinal data from Likertscales are transformed for descriptive as well as inferential purposes. This extends to the incorporation of data into correlational, regression, cluster and path analysis as well as structural equation and latent growth curve modelling. With the involvement of qualitative data notably subordinate to quantitative, judgements arising from the use of more open-ended questionnaires or from interviews have also relied upon the retrospective attribution of meaning with little opportunity for independent verification over time. More qualitative and mixed-methods approaches are certainly essential if the field is to become more fully informed. Both questionnaires and interviews can also suffer from other unwanted effects including social desirability bias, image 
management, integrity and honesty and the general emotional state of respondents at the time of participation. Interestingly, those students more prone to academic boredom than others are also more likely to absent themselves from participation as a result of self-selection, assuming, of course, they are present and able to participate at all.

\section{In conclusion}

Converging evidence from the literature reviewed and presented here strongly suggests that the academic boredom observed among undergraduate students at university is an achievement-related emotion worthy of serious consideration. As indicated by Pekrun (2006):

'... emotions can affect students' interest, engagement, achievement and personality development, as well as the social climate in [different] educational institutions ... emotions are [also] central to psychological health and wellbeing, implying that they should be regarded as important educational outcomes in themselves, independent of their functional relevance ...' (333334)

In the UK, the study of academic boredom as part of a greater emotional dynamic and integrated network of other causal factors associated with student engagement and achievement is only now beginning to attract the attention it deserves. In a sector receiving unprecedented numbers of students from increasingly diverse social and educational backgrounds, with thoughts turning more and more to teaching excellence, student satisfaction, retention and value for money, perhaps the time for action has arrived.

\section{Endnote}

Our search for relevant literature began by entering 'boredom' into Google Scholar (295,000 outcomes), ERIC (728 outcomes), psychINFO (2,910 outcomes) and psychArticles (146 outcomes) in turn. Google Scholar proved particularly valuable in locating sources across a range of disciplines other than education and psychology, with the number of outcomes reduced to only 175 using 'boredom' in combination with 
other key words of interest (e.g. 'undergraduate', 'engagement', 'achievement-related emotion', 'Control-Value Theory', 'AEQ', 'LRBS' and 'university'). Of interest, and prior to the emergence of Control-Value Theory, the majority of studies involving undergraduate students were undertaken in the United States and focused largely on definitions, instrumentation, trait boredom, boredom proneness and correlated behaviours. Following the emergence of Control-Value Theory, this emphasis shifted to include Germany and Canada, with other countries now increasingly involved. Greater consideration was also directed towards state boredom alongside intrinsic motivation, self-regulated learning and perceived effort as well as achievement. While attempting to maintain consistency in the quality of sources and information available, we acknowledge the possibility of publication and selection bias as a result of our methods and choices (e.g. citation frequency, ease of access, the exclusion unpublished work and accepting material only published in English).

\section{References}

Abramson, E.E. and Stinson, S.G. (1977) Boredom and eating in obese and nonobese individuals. Addictive Behaviors, 2(4), 181-185.

Acee, T.W., Kim, H., Kim, H.J., Chu, H.R., Kim, M., Cho, Y. and Wicker, F.W. (2010) Academic boredom in under- and over-achieving situations. Contemporary Educational Psychology, 35(1), 17-27.

Ahmed, S.M. (1990) Psychometric properties of the boredom proneness scale. Perceptual and Motor Skills, 71(3), 963-966.

Alda, M., Minguez, J., Montero-Martin, J., Gili, M., Puebla-Guedea, M., HerreraMercadal, P., Navarro-Gil, M. and Garcia-Campayo, J. (2015) Validation of the Spanish version of the MSBS. Health and Quality of Life Outcomes, 13:59, Open access: DOI 10.1186/s12955-0252-2.

Aldridge, M. and DeLucia, R. (1989) Boredom: The academic plague of first year students. Journal of the First-Year Experience and Students in Transition, 1(2), 43-56.

Altay, E. (2016) Unidirectional cycles of boredom, boredom coping strategies and engagement among prospective teachers. Social Psychology of Education: An International Journal, 19(4), 895-924. 
Altay, E. and Coskun, H. (2016) Students' level of boredom, boredom coping strategies, epistemic curiosity and graded performance. The Journal of Educational Research, 109(6), 574-588.

Amos, A., Wiltshire, S., Haw, S. and McNeill, A. (2006) Ambivalence and uncertainty: Experiences of and attitudes toward addiction and smoking cessation in midto late-teens. Health Education Research, 21(2), 181-191.

Artino, A.R. (2009) Think, feel, act: Motivational and emotion influences on military students' online academic success. Journal of Computing in Higher Education, 21(2), 146-166.

Artino, A.R. and Jones, K.D. (2012) Exploring the complex relations between achievement emotions and self-regulated learning behaviors in online learning. Internet and Higher Education, 15, 170-175.

Artino, A.R. and Stephens, J.M. (2009) Beyond grades in online learning: Adaptive profiles of academic self-regulation among naval academy undergraduates. Journal of Advanced Academics, 20(4), 568-601.

Artino, A.R., Rochelle, J.S.L. and Durning, S.J. (2010) Second-year medical students' motivational beliefs, emotions and achievement. Medical Education, 44(12), 1203-1212.

Artino, A.R., Holmboe, E.S. and Durning, S.J. (2012) Control-value theory: Using achievement emotions to improve understanding of motivation, learning, and performance in medical education: AMEE Guide No. 64, Theories in Medical Education. Medical Teacher, 34(3), e148-e160. Online: www. google.co.uk/\#q=control+value+theory+education.

Ashwin, P. (ed.) (2015) Reflective teaching in Higher Education. London: Bloomsbury.

Asikainen, H., Hailikari, T. and Mattson, M. (2017) The interplay between academic emotions, psychological flexibility and self-regulation as predictors of academic achievement. Journal of Further and Higher Education. Online: DOI 10.1080/0309877X.2017.1281889.

Bailey, J.P., Thackray, R.I., Pearl, J. and Parish, T.S. (1976) Boredom and arousal: Comparison of tasks differing in visual complexity. Perceptual and Motor Skills, 43(1), 141-142.

Baker, R.S., D'Mello, S.K., Rodrigo, M.T. and Graesser, A.C. (2010) Better to be 
frustrated than bored: The incidence, persistence and impact of learners' cognitive-affective states during interactions with three different computerbased learning environments. International Journal of Human Computer Studies, 68(4), 223-241.

Bandura, A. (1993) Perceived self-efficacy in cognitive development and functioning. Educational Psychologist, 28(2), 117-48.

Barbalet, J.M. (1999) Boredom and social meaning. British Journal of Sociology, 50(4), 631-646.

Bardgill, R.W. (2000) The study of life boredom. Journal of Phenomenological Psychology, 31(2), 188-219.

Barefoot, B.O. (2004) Higher education's revolving door: Confronting the problem of student drop out in US colleges and universities. The Journal of Open, Distance and E-learning, 19(1), 9-18.

Barmack, J.E. (1937) Boredom and other factors in the physiology of mental efforts: An exploratory study. Archives of Psychology, 218, 6-81.

Barmack, J.E. (1938) The effect of benzidrine sulphate (benzl-methyl-carbinamide) upon the report of boredom and other factors. Journal of Psychology, 5(1), 125133.

Barnett, L.A. (2005) Measuring the ABCs of leisure experience: Awareness, boredom, challenge, distress. Leisure Sciences: An Interdisciplinary Journal, 27(2), 131155.

Barnett, L.A. and Klitzing, S.W. (2006) Boredom in free time: Relationships with personality, affect and motivation for different genders, racial and ethnic groups. Leisure Sciences: An Interdisciplinary Journal, 28(3), 223-244.

Bartsch, R.A. and Cobern, K.M. (2003) Effectiveness of PowerPoint presentations in lectures. Computers and Education, 41(1), 77-86.

Belton, T. and Priyadharshini, E. (2007) Boredom and schooling: A cross-disciplinary exploration. Cambridge Journal of Education, 37(4), 579-595.

Bench, S.W. and Lench, H.C. (2013) On the function of boredom. Behavioral Sciences, 3(3), 459-472.

Bench, S.W. and Lench, H.C. (2018) Boredom as a seeking state: Boredom prompts 
the pursuit of novel (even negative) experiences. Emotion. Online: DOI 10.1037/emo0000433.

Binnema, D. (2004) Interrelations of psychiatric patient experiences of boredom and mental health. ProQuest Nursing Journals, 24(8), 833.

Blunt, A. and Pychyl, T.A. (1998) Volitional action and inaction in the lives of undergraduate students: State orientation, procrastination and proneness to boredom. Personality and Individual Differences, 24(6), 837-846.

Bolkan, S. and Griffin, D.J. (2017) Students' use of cell phones in class for off-task behaviors: The indirect impact of instructors' teaching behaviors through boredom and students' attitudes. Communication Education, 66(3), 313-329.

Brissett, D. and Snow, R.P. (1993) Boredom: Where the future isn't. Symbolic Interaction, 16(3), 237-256.

Britton, A. and Shipley, M.J. (2010) Bored to death? Journal of Epidemiology, 39(2), 370-371.

Bruursima, K., Kessler, S.R. and Spector, P.E. (2011) Bored employees misbehaving: the relationship between boredom and counterproductive work behaviour. Work and Stress, 25(2), 93-107.

Bryant, J. and Zillman, D. (1984) Using television to alleviate boredom and stress:

Selective exposure as a function of induced excitational states. Journal of Broadcasting and Electronic Media, 28(1), 1-20.

Caldwell, L.L., Darling, N., Payne, L.L. and Dowdy, B. (1999) 'Why are you bored?' An examination of psychological and social control causes of boredom among adolescents. Journal of Leisure Research, 31(2), 103-121.

Chien-Hsin, L., Shong-Lin, L and Chin-Pi, W. (2009) The effects of parental monitoring and leisure boredom on adolescents' internet addiction. Adolescence, 44 (176), 993-1004.

Chin, A., Markey, A., Bhargava, S., Kassam, K.S. and Loewenstein, G. (2017) Bored in the USA: Experience sampling and boredom in everyday life. Emotion, 17(2), 359-368.

Christie, H., Tett, L., Cree, V.E., Hounsell, J. and McCune, V. (2008) 'A real rollercoaster of confidence and emotions': Learning to be a university student. Studies in Higher Education, 33(5), 567-581. 
Craparo, G., Faraci, P., Fasciano, S., Carrubba, S. and Gori, A. (2013) A factor analytic study of the Boredom Proneness Scale (BPS). Clinical Neuropsychiatry: Journal of Treatment Evaluation, 10(3-4), 164-170.

Csikszentmihalyi, M. (1975) Beyond boredom and anxiety. San Francisco, CA: JosieBass.

Cullingford, C. (2002) The best years of their lives? Pupils' experience of school. London: Kogan Page.

Dahlen, E.R., Martin, R.C., Ragan, K. and Kuhlman, M.M. (2004) Boredom proneness in anger and aggression: Effects of impulsiveness and sensation seeking. Personality and Individual Differences, 37(8), 1615-1627.

Dahlen, E.R., Martin, R.C., Ragan, K. and Kuhlman, M.M. (2005) Driving anger, sensation seeking, impulsiveness and boredom proneness in the prediction of unsafe driving. Accident Analysis and Prevention, 37(2), 341-348.

Damrad-Frye,R. and Laird, J.D. (1989) The experience of boredom: The role of the self-perception of attention. Journal of Personality and Social Psychology, 57(2), 315-320.

Danckert, J.A. and Allman, A.A. (2009) Time flies when you're having fun: Temporal estimation and the experience of boredom. Brain and Cognition, 59(3), 236-245.

Daniels and Stupnisky (2012) Not that different in theory: Discussing the control-value theory of emotions in online learning environments. The Internet and Higher Education, 15(3), 222-226.

Daniels, L.M., Haynes, T.L., Stupnisky, R.H., Perry, R.P., Newall, N.E. and Pekrun, R. (2008) Individual differences in achievement goals: A longitudinal study of cognitive, emotional and achievement outcomes. Contemporary Educational Psychology, 33(4), 584-608.

Daniels, L.M., Stupnisky, R.H., Pekrun, R., Haynes, T.L., Perry, R.P. and Newall, N.E. (2009) A longitudinal analysis of achievement goals: From affective antecedents to emotional effects and achievement outcomes. Journal of Educational Psychology, 101(4), 948-963.

Daniels, E.C., Tze, V.M.C. and Goetz, T. (2015) Examining boredom: Different causes for different coping profiles. Learning and Individual Differences, 37(1), 255-261.

Darden, D.K. and Marks, A.H. (1999) Boredom: A socially disvalued emotion. Sociological Spectrum, 19(1), 13-37. 
Daschmann, E.C., Goetz, T. and Stupnisky, R.H. (2011) Testing the predictors of boredom at school: Development and validation of the precursors to boredom scales. British Journal of Educational Psychology, 81(3), 421-440.

Davies, P. (2000) The relevance of systematic reviews to educational policy and practice. Oxford Review of Education, 26(3\&4), 365-378.

De Chenne, T.K. (1988) Boredom as a clinical issue. Psychotherapy, 25(1), 71-81.

D'Mello, S. and Graesser, A. (2009) Automatic detection of learner's affect from gross body language. Applied Artificial Intelligence, 23(2), 123-150.

Drory, A. (1982) Individual differences in boredom proneness and task effectiveness at work. Personal Psychology, 35(1), 267-274.

Dumas, L. (2001) Why mistakes happen even when the stakes are high: The many dimensions of human fallibility. Medicine and Global Survival, 7(1), 12-19.

Dursun, P. and Tezer, E. (2013) Turkish adaptation of the boredom proneness scale short-form. Procedia: Social and behavioural Sciences, 84(2), 1550-1554.

Eastwood, J.D., Cavaliere, C., Fahlman, S.A. and Eastwood, J.D. (2007) A desire for desires: Boredom and its relation to alexithymia. Personality and Individual Differences, 42(6), 1035-1045.

Eastwood, J.D., Frischen, A., Fenske, M. and Smilek, D. (2012) The unengaged mind: Defining boredom in terms of attention. Perspectives on Psychological Science, 7(5), 482-495.

Elhai, J.D., Vasquez, J.K., Lustgarten, S.D., Levine, J.C. and Hall, B.J. (2017) Proneness to boredom mediates relationships between problematic smartphone use with depression and anxiety severity. Social Science Computer Review. Online: DOI 10.1177/0894439317741087.

Elpidorou, A. (2017) The good of boredom. Philosophical Psychology. Online: DOI 10.1080/09515089.2017.1346240.

Entwistle, N.J. (2009) Teaching for understanding at university. London: Palgrave Macmillan.

Entwistle, N., McCune, V. and Hounsell, J. (2002) Approaches to studying and perceptions of university teaching-learning environments: Concepts, measures and preliminary findings. Occasional Report 1 . Available at: 
www.etl.tla.ed.ac.uk/docs/ETLreport1.pdf.

Fahlman, S.A., Mercer-Lynn, K.B., Gaskovski, P., Eastwood, A.E. and Eastwood, J.D. (2009) Does a lack of life meaning cause boredom? Results from psychometric, longitudinal and experimental analyses. Journal of Social and Clinical Psychology, 28(3), 307-340.

Fahlman, S.A., Mercer-Lynn, K.B., Flora, D.B. and Eastwood, J.D. (2013) Development and validation of the multidimensional state boredom scale. Assessment, 20(1), 68-85.

Fallis, R.K. and Opotow, S. (2003) Are students failing school or are schools failing students? Class cutting in High School. Journal of Social Issues, 59(1), 103-119.

Farmer, R. and Sundberg, N.D. (1986) Boredom proneness: The development and correlates of a new scale. Journal of Personality Assessment, 50(1), 4-17.

Fenichel, O. (1951) On the psychology of boredom. In: D. Rapaport (ed.) Organization and pathology of thought. New York, NY: Columbia University Press. 349-361.

Ferrell, J. (2004) Boredom, crime and criminology. Theoretical Criminology, 8(3), 287-302.

Fisher, C.D. (1993) Boredom at work: A neglected concept. Human Relations, 46(3), 395-418.

Fiske, D.W. and Maddi, S.R. (1961) Functions of varied experience. Homewood, II: Dorsey.

Fogelman, K. (1976) Bored eleven-year-olds. British Journal of Social Work, 6(2), 201-211.

Frenzel, A.C., Pekrun, R. and Goetz, T. (2007) Perceived learning environment and students' emotional experience: A multilevel analysis of mathematics classrooms. Learning and Instruction, 17(5), 478-493.

Frenzel, A.C., Goetz, T., Pekrun, R. and Watt, H.M.G. (2010) Development of mathematics interest in adolescents: Influences of gender, family and school context. Journal of Research on Adolescence, 20(2), 507-537.

Fry, H., Ketteridge, S. and Marshall, S. (eds.)(2014) A handbook for teaching and learning in higher education: Enhancing academic practice. London: Routledge. 
Gana, K. and Akremi, M. (1998) L'Échelle de disposition a l'ennui (EDE): adaptation françaisse et validation du boredom proneness scale (BP). The scale of tendency towards boredom (EDE). Trans: French adaptation and validation of the Boredom Proneness Scale (BP). L'Anée Psychologique, 98(3), 429-450.

Gana, K., Deletang, B. and Metais, L. (2000) Is boredom proneness associated with introspectiveness? Social Behavior and Personality, 28(5), 499-504.

Ganley, R.M. (1989) Emotion and eating in obesity: A review of the literature. International Journal of Eating Disorders, 8(3), 343-361.

Garn, A.C., Simonton, K., Dasingert, T. and Simonton, A. (2017) Predicting changes in student engagement in university physical education: Application of the control-value theory of achievement emotions. Psychology of Sport and Exercise, 29(1), 93-102.

Geiwitz, P.J. (1966) Structure of boredom. Journal of Personal and Social Psychology, 3(5), 592-600.

Gerritson, C.J., Toplak, M.E., Sciaraffa, J. and Eastwood, J.D. (2014) I can't get no satisfaction: Potential causes of boredom. Consciousness and Cognition, 27(1), 27-41.

Gjesme, T. (1977) General satisfaction and boredom at school as a function of the pupils' personality characteristics. Scandinavian Journal of Educational Research, 21(1), 113-146.

Goetz, T., Pekrun, R., Hall, N.C. and Haag, L. (2006a) Academic emotions from a social-cognitive perspective: Antecedents and domain specificity of students' affect in the context of Latin instruction. British Journal of Educational Psychology, 76(2), 289-308.

Goetz, T., Frenzel, A.C., Pekrun, R. and Hall, N.C. (2006b) The domain specificity of academic emotional experiences. Journal of Experimental Education, 75(1), 529.

Goetz, T., Frenzel, A.C., Pekrun, R., Hall, N.C. and Ludtke, O. (2007) Between- and within-domain relations of students' academic emotions. Journal of Educational Psychology, 99(4), 715-733.

Goetz, T., Frenzel, A.C., Stoeger, H. and Hall, N.C. (2010) Antecedents of everyday positive emotions: An experience sampling analysis. Motivation and Emotion, 34(1), 49-62. 
Goetz, T., Frenzel, A.C., Hall, N.C., Nett, U.E., Pekrun, R. and Anatstasiya, A.L. (2014) Types of boredom: An experience sampling approach. Motivation and Emotion, 38(3), 401-419.

Goldberg, Y.K., Eastwood, J.D., Laguardia, J. and Danckert, J. (2011) Boredom: an emotional experience distinct from apathy, anhedonia, or depression. Journal of Social and Clinical Psychology, 30(6), 647-666.

Gordon, A., Wilkinson, R., McGowan, A. and Jovanskoska, S. (1997) The psychometric properties of the boredom proneness scale: An examination of its validity. Psychological Studies, 42(2\&3), 85-97.

Govaerts, S. and Grégoire, J. (2008) Development and construct validation of an academic emotions scale. International Journal of Testing, 8(1), 34-54.

Greenson, R. (1953) On boredom. Journal of the American Psychoanalytical Association, 1(1), 7-21.

Grubb, E.A. (1975) Assembly line boredom and individual differences in recreation participation. Journal of Leisure Research, 7(4), 256-269.

Hagenauer, G., Gläser-Zikuda, M. and Moschner, B. (2017) University students' emotions, life-satisfaction and study commitment: A self-determination theoretical perspective. Journal of Further and Higher Education. Online: DOI 10.1080/0309877X.2017.1323189.

Haladyn, J.J. (2015) Boredom and art: Passions of the will to boredom. Alresford: Zero Books.

Hamilton, J.A., Haier, R.J. and Buchsbaum, M.S. (1984) Intrinsic enjoyment and boredom coping scales: Validation with personality, evoked potential and attention measures. Personality and Individual Differences, 5(2), 183-193.

Harasymchuk, J. and Fehr, B. (2012) A proto-type analysis of relationship boredom. Journal of Social and Personal Relationships, 30(5), 627-646.

Harris, M.B. (2000) Correlates and characteristics of boredom proneness and boredom. Journal of Applied Social Psychology, 30(3), 576-598.

Haynes, T.L., Perry, R.P., Stupnisky, R.H. and Daniels, L.M. (2009) A review of attributional retraining treatments: Fostering engagement and persistence in vulnerable college students. In: J.C. Smart (ed.) Higher Education Handbook of Theory and Research. Dordrecht: Springer. 227-272. 
Healy, S.D. (1986) Boredom, self and culture. Cranbury, NJ: Associated University Presses.

Heckel, C. and Ringeisen, T. (2017) Enjoyment and boredom in academic onlinelearning: Relations with appraisals and learning outcomes. In: K.A. Moore and P. Buchwald (eds.) Stress and Anxiety: Coping and Resilience. Berlin, Germany: Logos Verlag Berlin GmbH. 27-136.

Heron, W. (1957) The pathology of boredom. Scientific American, 196, 52-56.

Hill, A.B. (1975) Extroversion and variety seeking in a monotonous task. British Journal of Psychology, 66, 9-13.

Hill, A.B. and Perkins, R.E. (1985) Towards a model of boredom. British Journal of Psychology, 76(2), 235-240.

Hodgkins, D.C. and Rucicot, S. (2013) The link between drinking and gambling among undergraduate university students. Psychology of Addictive Behaviors, 27(3), 885-892.

Hong, J., Heddy, B., Ruan, J., You, S., Kambara, H., Nie, Y. and Monobe, G. (2016) Revising and Validating Achievement Emotions Questionnaire-Teachers (AEQT). International Journal of Educational Psychology, 5(1), 80-107.

Hounsell, D. and Entwistle, N. (2005) Enhancing teaching-learning environments in undergraduate courses: Final report to the Economic and Social research Council. Edinburgh: University of Edinburgh. Available at: www.etl.tla.ed.ac.uk.

Illeris, K. (2003) The three dimensions of learning: Contemporary learning theory in the tension field between the cognitive, the emotional and the social. Leicester: NIACE.

Iso-Ahola, S.E. and Crowley, E.D. (1991) Adolescent substance abuse and leisure boredom. Journal of Leisure Research, 23(3), 260-271.

Iso-Ahola, S.E. and Weissinger, E. (1990) Leisure and boredom. Journal of Social and Clinical Psychology, 5(3), 356-364.

Johnston, J.D. and O'Malley, P.M. (1986) Why do the nation's students use drugs and alcohol? Self-reported reasons from nine national surveys. Journal of Drug Issues, 16(1), 29-66.

Kahu, E., Stephens, C, Leach, L. and Zepke, N. (2015) Linking academic emotions 
and student engagement: Mature-aged distant students' transition to university. Journal of Further and Higher Education, 39(4), 481-497.

Kalpidou, M., Costin, D. and Morris, J. (2011) The relationship between Facebook and the well-being of undergraduate college students. Cyberpsychology, Behavior and Social Networking, 14(4), 183-199.

Kanevsky, L. and Keighley, T. (2003) To produce or not to produce: Understanding Boredom and the honor in underachievement. Roeper Review, 26(1), 20-28.

Kass, S.J. and Vodanovich, S.J. (1990) Boredom proneness: Its relationship to Type A behaviour patterns and sensation seeking. Psychology: A Journal of Human Behavior, 27(3), 7-16.

Kass, S.J., Beede, K.E. and Vodanovich, S.J. (2010) Self-report measures of distractibility as correlates of driving performance. Accident Analysis and Prevention, 42(3), 874-880.

Kass, S.J., Vodanovich, S.J. and Callender, A. (2001a) State-trait boredom:

Relationships to absenteeism, tenure and job satisfaction. Journal of Business and Psychology, 16(2), 317-327.

Kass, S.J., Vodanovich, S.J., Stanny, C.J. and Taylor, T.M. (2001b) Watching the clock: Boredom and vigilance performance. Perceptual and Motor Skills, 92(3), 969-976.

Kass, S.J., Wallace, C. and Vodanovich, S.J. (2003) Boredom proneness and sleep disorders as predictors of adult attention deficit scores. Journal of Attentional Disorders, 7(2), 83-91.

Kass, S.J., Vodanovich, S.J. and Khosravi, J.Y. (2011) Applying the job characteristics model to the college educational experience. Journal of Scholarship of Teaching and Learning, 11(4), 56-68.

Keleş, H.N. and Özkan, T.K. (2011) Positive organizational behaviour variables and the effects of boredom proneness on perceived organizational support. International Journal of Management and Information, 15(4), 133-139.

Kinchin, I.M., Chadha, D. and Kokotailo, P. (2008) Using PowerPoint as a lens to focus on linearity in teaching. Journal of Further and Higher Education, 32(4), 333-346.

Larson, R.W. (1991) Boredom in the middle school years: Blaming schools vs blaming students. American Journal of Education, 99(4), 418-443. 
Leary, M.L., Rogers, P.A., Canfield, R.W. and Coe, C. (1986) Boredom in interpersonal encounters: Antecedents and social implications. Journal of Personality and Social Psychology, 51(5), 968-975.

Lee, T.W. (1986) Towards the development and validation of a measure of job boredom. Manhattan College Journal of Business, 15(1), 22-28.

LePera, N. (2011) Relationships between boredom proneness, mindfulness, anxiety, depression and substance abuse. New School Psychology Bulletin, 8(2), 1525.

Lepp, L., Li, J., Barkley, J.E. and Salehi-Esfahani, S. (2015) Exploring the relationship between college student' cell phone use, personality and leisure. Computers in Human Behavior, 43(1), 210-219.

Lewinsky, H. (1943) Boredom. British Journal of Educational Psychology, 13(3), 147152.

Li, W., O'Brien, J.E., Snyder, S.M. and Howard, M.O. (2015) Characteristics of Internet addiction/pathological Internet use in US university students: A qualitativemethod investigation. PLOSONE, 10(2), 1-19.

Lichtenfeld, S., Pekrun, R., Stupnisky, R., Reiss, K. and Murayama, K. (2012) Measuring students' emotions in the early years: The Achievement Emotions Questionnaire-Elementary School (AEQ-ES). Learning and Individual Differences, 22(2), 190-201.

Linnenbrink-Garcia, E.A. and Pekrun, R. (2011) Students' emotions and academic engagement. Contemporary Educational Psychology (Special Issue), 36(1), 13.

Liu, Y., Chen, J., Jiang, M., Xu, H., Liu, J., Eastwood, J.D. and Mehranvar, S. (2013) The Chinese version of the Multidimensional State Boredom Scale (MSBS): Its applicability in Chinese college students. Chinese Journal of Clinical Psychology, 21(1), 558-562.

Loken, J. (1973) Patterns of drug misuse and the school drop-out. Canadian Counsellor, 7(4), 279-282.

London, H., Schuber, D.S.P. and Washburn, D. (1972) Increase of autonomic arousal by boredom. Journal of Abnormal Psychology, 80(1), 29-36.

Loon, M. and Bell, R. (2017) The moderating effects of emotions on cognitive skills. 
Journal of Further and Higher Education. Online: DOI 10.1080/0309877X.2017.1311992.

Loukidou, L., Loan-Clarke, J. and Daniels, K. (2009) Boredom in the workplace: More than monotonous tasks. International Journal of Management Reviews, 11(4), 381-405.

MacDonald, D.A. and Holland, D. (2002) Spirituality and boredom proneness. Personality and Individual Differences, 32(6), 1113-1119.

Macklem, G.L. (2015) Boredom in the classroom: Addressing student motivation, selfregulation and engagement in learning. New York, NY: Springer.

Malkovsky, E., Merrifield, C., Goldberg, Y. and Danckert, J. (2012) Exploring the relationship between boredom and sustained attention. Experimental Brain Research, 221(1), 59-67.

Maltsberger, J.T. (2000) Mansur Zaskar: A man almost bored to death. Suicide and Life-Threatening Behaviour, 30(1), 83-90.

Mann, S. (2007) The boredom boom. The Psychologist, 20(2), 90-93.

Mann, S. (2016) The upside of downtime: Why boredom is good. London: Robinson.

Mann, S. and Cadman, R. (2014) Does being bored make us more creative? Creativity Research Journal, 26(2), 165-173.

Mann, S. and Robinson, A. (2009) Boredom in the lecture theatre: An investigation into the contributors, moderators and outcomes of boredom amongst university students. British Educational Research Journal, 35(2), 243-258.

Maroldo, G.K. (1986) Shyness, boredom and grade point average among college students. Psychological Reports, 59(2), 395-398.

Martin, M., Sadlo, G. and Stew, G. (2006) The phenomenon of boredom. Qualitative Research in Psychology, 3(3), 193-211.

McCoy, B. (2013) Digital distractions in the classroom: Student classroom use of digital devices for non-class related purposes. Faculty Publications, College of Journalism and Mass Communications, 71, 1-16.

McDowell, R.J.S. and Wells, H.M. (1927) The physiology of monotony. British Medical Journal, 1(3452), 414-415. 
McGiboney, G.W. and Carter, C. (1988) Boredom proneness and adolescents' personalities. Psychological Reports, 63(3), 741-742.

McLeod, C.R. and Vodanovich, S.J. (1991) The relationship between self-actualisation and boredom proneness. Journal of Social Behaviour and Personality, 6(5), 137-146.

Mega, C., Ronconi, L. and Beni, R.D. (2014) What makes a good student? How emotions, self-regulated learning and motivation contribute to academic achievement. Journal of Educational Psychology, 106(1), 121-131.

Melton, A.M.A. and Schulenberg, S.E. (2009) A confirmatory factor analysis of the boredom proneness scale. The Journal of Psychology, 143(5), 493-508.

Mercer, K.B. and Eastwood, J.D. (2010) Is boredom associated with problem gambling behaviour? It depends on what you mean by 'boredom'. International Gambling Studies, 10, 91-104.

Mercer-Lynn, K.B., Bar, R.J. and Eastwood, J.D. (2014) Causes of boredom: The person, the situation or both? Personality and Individual Differences, 56(1), 122-126.

Mercer-Lynn, K.B., Flora, D.B., Fahlman, S.A. and Eastwood, J.D. (2011) The measurement of boredom: Differences between existing self-report scales. Assessment, 20(5), 585-596.

Mercer-Lynn, K.B., Hunter, J.A. and Eastwood, J.D. (2013) Is trait boredom redundant? Journal of Social and Clinical Psychology, 32(8), 897-916.

Merrifield, C. and Danckert, J. (2014) Characterising the psychophysiological signature of boredom. Experimental Brain Research, 232(2), 481-491.

Miller, J.A., Caldwell, L.L., Weybright, E.H., Smith, E., Vergnani, T. and Wegner, L. (2014) Was Bob Seger right? Relation between boredom in leisure and [risky] sex. Leisure Sciences: An Interdisciplinary Journal, 36(1), 52-67.

Mikulas, W.L. and Vodanovich, S.J. (1993) The essence of boredom. The Psychological Record, 43(1), 3-12.

Moynihan, A.B., van Tilberg, W.A.P., Igou, E.R., Wiseman, A., Donnelley, A.E. and Mulcaire, J.B. (2015) Eaten up by boredom: Consuming food to escape awareness of the bored self. Frontiers in Psychology, 6 (369), 1-10.

Nett, U.E., Daschmann, E.C., Goetz, T. and Stupnisky, R.H. (2016) How accurately 
can parents judge their children's boredom in school? Frontiers in Psychology, $7(770), 1-14$.

Nett, U.E., Goetz, T. and Daniels, L.M. (2010) What to do when feeling bored? Students' strategies for coping with boredom. Learning and Individual Differences, 20(6), 626-638.

Nett, U.E., Goetz, T. and Hall, N.C. (2011) Coping with boredom in school: An experience sampling perspective. Contemporary Educational Psychology, 36(1), 49-59.

Neu, J. (1998) Boring from within: Endogenous vs reactive boredom. In: W.F. Flack and J.D. Laird (eds) Emotions in psychopathology: Theory and research. London: Oxford University Press. 158-170.

Newberry, A.L. and Duncan, R.D. (2001) Roles of boredom and life goals in juvenile delinquency. Journal of Applied Social Psychology, 31(3), 527-541.

Ng, A.H., Liu, Y., Chen, J. and Eastwood, J.D. (2015) Culture and state boredom: A comparison between European Canadians and Chinese. Personality and Individual Differences, 75, 13-18.

Noteborn, G., Carbonell, K.B., Dailey-Hebert, A. and Gijselaers, W. (2012) The role of emotions and task significance in virtual education. Internet and Higher Education, 15(3), 176-183.

O'Connor, D. (1967) The phenomenon of boredom. Journal of Existentialism, 7(27), 381-399.

O'Hanlon, J.F. (1981) Boredom: Practical consequences and a theory. Acta Psychologica, 49(1), 53-82.

Orcutt, J.D. (1984) Contrasting effects of two kinds of boredom on alcohol use. Journal of Drug Issues, 14(1), 161-173.

Passik, S.D, Inman, A., Kirsh, K., Theobald, D. and Dickerson, P. (2003) Initial validation of a scale to measure purposelessness, under-stimulation and boredom in cancer patients: Towards a redefinition of depression in advanced disease. Palliative and Supportive Care, 1(1), 41-50.

Patti, P., Perry, R.P., Chipperfield, J.G., Hamm, J.M. and Pekrun, R. (2018) An attribution-based motivation treatment for low control students who are bored in online environments. Motivational Science, 4(2), 177-184. 
Paulson, M.J., Coombs, R.H. and Richardson, M.A. (1990) School performance, academic aspirations and drug use among children and adolescents. Journal of Drug Education, 20(4), 289-303.

Peixoto, F., Mata, L., Monteiro, V. and Sanches, C. (2015) The Achievement Emotions Questionnaire: Validation for pre-adolescent students. European Journal of Developmental Psychology, 12(4), 472-481.

Peixoto, F., Sanches, C., Lourdes, M. and Monteiro, V. (2017) 'How do you feel about math?' Relationships between competence and value appraisals, achievement emotions and academic achievement. European Journal of Psychology of Education, 32(3), 385-405.

Pekrun, R. (1984) An expectancy-value model of anxiety. In: H.M. van der Ploeg, R. Schwarzer and C.D. Spielberger (eds.) Advances in Test Anxiety Research (3). Lisse, The Netherlands: Swets and Zeitlinger. 53-72.

Pekrun, R. (1992a) The impact of emotions on learning and achievement: Towards a theory of cognitive/motivational mediators. Applied Psychology, 41(4), 359376.

Pekrun, R. (1992b) The expectancy-value theory of anxiety: Overview and implications. In: D.G. Forgays, T. Sosnowski and K. Wrzesniewski (eds.) Anxiety: Recent developments in self-appraisal, psychophysiological and health research. Washington, DC: Hemisphere. 23-41.

Pekrun, R. (2000) A social-cognitive, control-value theory of achievement emotions. In: J. Heckhausen (ed.) Motivational psychology of human development. Oxford: Elsevier Science. 143-163.

Pekrun, R. (2006) The control-value theory of academic emotions: Assumptions, corollaries and implications for educational practice. Educational Psychology Review, 18(4), 315-341.

Pekrun, R., Götz, T., Titz, W. and Perry, R.P. (2002a) Positive emotions in education. In: E. Frydenberg (ed.) Beyond coping: Meeting goals, visions and challenges. Oxford, UK: Elsevier. 149-174.

Pekrun, R. and Stevens, E.J. (2010) Achievement emotions: A control-value approach. Social and Personality Psychology Compass, 4(4), 238-255.

Pekrun, R., Elliot, A.J. and Maier, M.A. (2009) Achievement goals and achievement emotions: Testing a model of their joint relations with academic performance. Journal of Educational Psychology, 101(1), 115-135. 
Pekrun, R., Goetz, T., Titz, W.and Perry, R.P. (2002b) Academic emotions in students' self-regulated learning and achievement: A programme of quantitative and qualitative research. Educational Psychologist, 37(2), 91-106.

Pekrun, R., Goetz, T. and Perry, R.P. (2005a) Achievement Emotions Questionnaire (AEQ): User's manual. Munich, Germany: Department of Psychology, University of Munich.

Pekrun, R., Goetz, T. and Frenzel, A.C. (2005b) Achievement Emotions Questionnaire - Mathematics (AEQ-M). User's Manual. Munich, Germany: Department of Psychology, University of Munich.

Pekrun, R., Goetz, T., Daniels, L.M., Stupinsky, R.H. and Perry, R.P. (2010) Boredom in achievement setting: Exploring control-value antecedents and performance outcomes of a neglected emotion. Journal of Educational Psychology, 102(3), 531-549.

Pekrun, R., Goetz, T., Frenzel, A.C., Barchfeld, P. and Perry, R.P. (2011) Measuring emotions in students' learning and performance: The Achievement Emotions Questionnaire (AEQ). Contemporary Educational Psychology, 36(1), 36-48.

Pekrun, R., Hall, N.C., Goetz, T. and Perry, R.P. (2014) Boredom and academic achievement: Testing a model of reciprocal causation. Journal of Educational Psychology, 106(3), 696-710.

Perkins, R.E. and Hill, A.B. (1985) Cognitive and affective aspects of boredom. British Journal of Psychology, 76(2), 221-234.

Pempek, T.A., Yermolayeva, Y.A. and Calvert, S.L. (2009) College students' social networking experiences on Facebook. Journal of Applied Developmental Psychology, 30(3), 227-238.

Perry, R.P. (1991) Perceived control in college students: Implications for instruction in higher education. In: J. Smart (ed.) Higher Education: Handbook of Theory and Research (7). Dordrecht: Springer. 257-306.

Perry, R.P., Hladkyj, S., Pekrun, R.H., and Pelletier, S.T. (2001) Academic control and action control in the achievement of college students: A longitudinal field study. Journal of Educational Psychology, 93(4), 776-789.

Phillips, A. (1993) On kissing, tickling and being bored: Psychoanalytic essays on the unexamined life. Cambridge, MA: Harvard University Press. 
Piotrowski, C. (2013) Boredom research: An analysis of topical domain and historical trends. Journal of Instructional Psychology, 40(2), 50-52.

Polly, L.M., Vodanovich, S.J., Watt, J.D. and Blanchard, M.J. (1993) The effects of attributional processes on boredom proneness. Journal of Social Behavior and Personality, 8(1), 123-132.

Preckel, F., Götz, T. and Freznel, A. (2010) Ability grouping of gifted students: effects on academic self-concept and boredom. British Journal of Educational Psychology, 80(3), 451-472.

Putwain, D.W., Becker, S., Symes, W. and Pekrun, R. (2017) Reciprocal relations between students' academic enjoyment, boredom and achievement over time. Learning and Instruction. Online: DOI 10.1016/j.learninstruc.2017.08.004.

Ragheb, M.G. and Merydith, S.P. (2001) Development and validation of a multidimensional scale measuring free-time boredom. Leisure Studies, 20(1), 41 59.

Ranellucci, J., Hall, N.C., and Goetz, T. (2015) Achievement goals, emotions, learning and performance: A process model. Motivational Science, 1(2), 98-120.

Ratcliffe, K.G. and Burkhart, B.R. (1984) Sex differences in motivations for and effects of drinking among college students. Journal of Studies on Alcohol, 45(1), 2632.

Respondek, L., Seufert, T., Stupnisky, R. and Nett, U.E. (2017) Perceived academic control and academic emotions predict undergraduate university student success: Examining effects in dropout intention and achievement. Frontiers in Psychology, 8(243), 1-18.

Robinson, W.P. (1975) Boredom at school. British Journal of Educational Psychology, 45(2), 141-152.

Roick, J. and Ringeisen, T. (2017) Self-efficacy, test anxiety and academic success: A longitudinal validation. International Journal of Educational Research, 83, 8493.

Rupp, D.E. and Vodanovich, S.J. (1997) The role of boredom proneness in selfreported anger and aggression. Journal of Social Behavior and Personality, 12(4), 925-936.

Russell, J.A. (1980) A circumplex model of affect. Journal of Personality and Social Psychology, 39(6), 1161-1178. 
Ruthig, J.C., Perry, R.P., Hall, N.C. and Hladkyj, S. (2004) Optimism and attributional retraining: Longitudinal effects on academic achievement, test anxiety and voluntary course withdrawal in college students. Journal of Applied Social Psychology, 34(4), 709-730.

Ruthig, J.C., Perry, R., Hladkyj, S., Hall, N.C., Pekrun, R. and Chipperfield, J.G. (2008) Perceived control and emotions: Interactive effects on performance in achievement settings. Social Psychology of Education, 11(2), 161-180.

Scherer, K.R. (2000) Emotions as episodes of subsystems synchronization driven by non-linear appraisal processes. In: M.D. Lewis and I. Granic (eds.) Emotion, Development and Self-Organization. Cambridge, UK: Cambridge University Press. 70-79.

Scherer, K.R. (2005) What are emotions? And how can they be measured? Social Science Information, 44(4), 695-729.

Scherer, K.R. (2009) The dynamic architecture of emotion: Evidence for the component process model. Cognition and Emotion, 23(7), 1307-1351.

Schönwetter, D.J., Perry, R.P. and Struthers, C.W. (1993) Students' perceptions of control and success in the college classroom. Journal of Experimental Education, 61(3), 227-246.

Schubert, D.S.P. (1978) Creativity and coping with boredom. Psychiatric Annals, 8(3), 120-125.

Schukajlow, S. and Rakoczy, K. (2016) The power of emotions: Can enjoyment and boredom explain the impact of individual preconditions and teaching methods on interest and performance in mathematics? Learning and Instruction, 44, 117-127.

Schutz, P.A. and DeCuir, J.T. (2002) Inquiry on emotions and education. Educational Psychologist, 37(2), 125-135.

Schutz, P.A. and Pekrun, R. (eds.)(2007) Emotion in education. Burlington, MA: Academic Press.

Seib, H.M. and Vodanovich, S.J. (1998) Cognitive correlates of boredom proneness: The role of private self-consciousness and absorption. The Journal of Psychology, 132(6), 642-652.

Shani, P., Krajcevska, A. and Spector, P.E. (2018) Cyberloafing as a coping 
mechanism: Dealing with workplace boredom. Computers in Human Behavior, $86,147-152$.

Sharp, J. G., Hemmings, B. and Kay, R. (2016) Towards a model for the assessment of student boredom and boredom proneness in the UK Higher Education context. Journal of Further and Higher Education, 40(5), 649-681.

Sharp, J. G., Hemmings, B., Kay, R. and Atkin, C. (2018) Academic boredom, the approaches to learning and the final-year degree outcomes of undergraduate students. Journal of Further and Higher Education, 42(8), 1055-1077.

Sharp, J. G., Hemmings, B., Kay, R., Murphy, B. and Elliott, S. (2017a) Academic boredom among students in Higher Education: A mixed-methods exploration of characteristics, contributors and consequences. Journal of Further and Higher Education, 41(5), 657-677.

Sharp, J.G., Hemmings, B., Kay, R. and Sharp, J.C. (2017b) Academic boredom and the perceived course experiences of final year Education Studies students at university. Journal of Further and Higher Education. Online: DOI 10.1080/0309877X.2017.1386287.

Shaw, S. (1996) Boredom, stress and social control in the daily activities of adolescents. Journal of Leisure Research, 28(4), 274-292.

Skues, J., Williams, B., Oldmeadow, J. and Wise, L. (2016) The effects of boredom, loneliness, and distress tolerance on problem Internet use among university students. International Journal of Mental Health and Addiction, 14(2), 167-180.

Skues, J., Williams, B. and Wise, L. (2017) Personality traits, boredom and loneliness as predictors of Facebook use in on-campus and online university students. International Journal of Cyber Behavior, Psychology and Learning, 7(2), 36-48.

Smith, R.P. (1981) Boredom: a review. Human Factors, 23(3), 329-340.

Sommers, J. and Vodanovich, S.J. (2000) Vengeance scores among college students: Examining the role of jealousy and forgiveness. Education, 121(1), 114-119.

Song, H.J., Li, Y.M. and Li, Y.X. (2013) The application of the Multidimensional State Boredom Scale in Chinese students. Chinese Journal of Clinical Psychology, 21(5), 774-778.

Spacks, P.M. (1995) Boredom: The literary history of a state of mind. Chicago: University of Chicago Press. 
Stikney, M.I. and Miltenberger, R.G. (1999) Evaluating direct and indirect measures for the functional assessment of binge eating. International Journal of Eating Disorders, 26(2), 195-204.

Svendsen, L. (2005) A philosophy of boredom. London: Reaktion Books.

Tanaka, A. and Murayama, K. (2014) Within-person analysis of situational interest and boredom: Interaction between task-specific perceptions and achievement goals. Journal of Educational Psychology, 106(4), 1122-1134.

Thackray, R.I. (1981) The stress of boredom and monotony: A consideration of the evidence. Psychosomatic Medicine, 43(2), 165-167.

Thackray, R.I., Jones,K.N., and Touchstone, R.M. (1974) Personality and physiological correlates of performance decrement on a monotonous task requiring sustained attention. British Journal of Psychology, 65(3), 351-358.

Tidwell, R. (1988) Dropouts speak out: Qualitative data on early school departures. Adolescence, 23(92), 939-954.

Titley, R.W. and Titley, B.S. (1982) Academic advising: The neglected dimension in designs for undergraduate education. Teaching of Psychology, 9(1), 45-49.

Todman, M. (2003) Boredom and psychotic disorders: Cognitive and motivational issues. Psychiatry, 66(2), 146-167.

Todman, M. (2013) The dimensions of state boredom: Frequency, duration, unpleasantness, consequences and causal attributions. Educational Research International, 1(1), 32-40.

Tolor, A. (1989) Boredom as related to alienation, assertiveness, internal-external expectation and sleep patterns. Journal of Clinical Psychology, 45(2), 260-265.

Toohey, P. (2012) Boredom: A lively history. New Haven: Yale University Press.

Trigwell, K., Ellis, R.A. and Han, F. (2012) Relations between students' approaches to learning, experienced emotions and outcomes of learning. Studies in Higher Education, 37(7), 811-824.

Trowler, V. (2010) Student engagement: Evidence summary. York: HEA.

Tsapelas, I., Aron, A. and Orbuch, T. (2009) Marital boredom now predicts less satisfaction 9 years later. Psychological Science, 20(5), 543-545. 
Tze, V.M.C., Klassen, R.M., Daniels, L.M., Li, J.C-H. and Zhang, X. (2013a) A crosscultural validation of the Learning-Related Boredom Scale (LRBS) with Canadian and Chinese college students. Journal of Psychoeducational Assessment, 31(1), 29-39.

Tze, V.M.C., Klassen, R.M., Daniels, L.M. and Li, J.C-H. (2013b) Canadian and Chinese university students' approaches to coping with academic boredom. Learning and Individual Differences, 23, 32-43.

Tze, V.M.C., Daniels, L.M. and Klassen, R.M. (2014a) Examining the factor structure and validity of the English Precursors to Boredom Scale. Learning and Individual Differences, 32, 254-260.

Tze, V.M.C., Klassen, R.M. and Daniels, L.M. (2014b) Patterns of boredom and its relationship with perceived autonomy support and engagement. Contemporary Educational Psychology, 39(3), 175-187.

Tze, V., Daniels, L.M. and Klassen, R.M. (2016) Evaluating the relationship between boredom and academic outcomes: A meta-analysis. Educational Psychology Review, 28(1), 119-144.

Vandewiele, M. (1980) On boredom of secondary school students in Senegal. The Journal of Genetic Psychology, 137(2), 267-274.

van Tilberg, W.A.P. and Igou, E.R. (2011) On boredom and social identity: A pragmatic meaning-regulation approach. Personality and Social Psychology Bulletin, 37(12), 1679-1691.

van Tilberg, W.A.P. and Igou, E.R. (2012) On boredom: Lack of challenge and meaning as distinct boredom experiences. Motivation and Emotion, 36(2), 181194.

van Tilberg, W.A.P. and Igou, E.R. (2016) Going to political extremes in response to boredom. European Journal of Social Psychology, 46(6), 687-699.

van Tilberg, W.A.P., Igou, E.R., Maher, P.J., Moynihan, A.B. and Martin, D.G. (2018) Bored like hell: Religiosity reduces boredom and tempers the quest for meaning. Emotion. Online: DOI 10.1037/emo0000439.

Villavicencio, F.T. and Bernardo, A.B.I. (2013) Positive academic emotions moderate the relationship between self-regulation and academic achievement. British Journal of Educational Psychology, 83(2), 329-340.

Vodanovich, S.J. (2003a) On the possible benefits of boredom: A neglected area of 
personality research. Psychology and Education: An Interdisciplinary Journal, 40(3/4), 28-33.

Vodanovich, S.J. (2003b) Psychometric measures of boredom: A review of literature. The Journal of Psychology, 137(6), 569-595.

Vodanovich, S.J. and Kass, S.J. (1990a) A factor analytic study of the boredom proneness scale. Journal of Personality Assessment, 55(1\&2), 115-123.

Vodanovich, S.J. and Kass, S.J. (1990b) Age and gender differences in boredom proneness. Journal of Social Behavior and Personality, 5, 297-307.

Vodanovich, S.J. and Watt, J.D. (2016) Self-report measures of boredom: An updated review of the literature. The Journal of Psychology, 150(2), 196-228.

Vodanovich, S.J., Kass, S.J., Andrasic, F.G., Gerber, W-D, Niederberger, U. and Breau, C. (2011) Culture and gender differences in boredom proneness. North American Journal of Psychology, 13(2), 221-130.

Vodanovich, S.J., Verner, K.M., and Gilbride, T.V. (1991) Boredom proneness: Its relationship to positive and negative affect. Psychological Reports, 69, 11391146.

Vodanovich, S.J., Watt, J.D. and Piotrowski, C. (1997) Boredom proneness in African-American students: A factor analytic perspective. Education, 118, 229236.

Vodanovich, S.J., Wallace, J.C. and Kass, S.J. (2005) A confirmatory approach to the factor structure of the boredom proneness scale: Evidence for a two-factor short form. Journal of Personality Assessment, 85(3), 295-303.

Vogel-Walcutt, J.J., Fiorella, L., Carper, T. and Schatz, S. (2012) The definition, assessment and mitigation of state boredom within educational settings: A comprehensive review. Educational Psychology Review, 24(1), 89-111.

Wallace, J.C., Vodanovich, S.J. and Restino, B. (2003) Predicting cognitive failures from boredom proneness and daytime sleepiness scores: An investigation within military and undergraduate samples. Personality and Individual Differences, 34(4), 635-644.

Wallbott, H.G. (1998) Bodily expressions of emotion. European Journal of Social Psychology, 28(6), 879-896.

Wan, H.C., Downey, L.A. and Stough, C. (2014) Understanding non-work 
presenteeism: Relationships between emotional intelligence, boredom, procrastination and job stress. Personality and Individual Differences, 65, 8690.

Wasson, A.S. (1981) Susceptibility to boredom and deviant behaviour at school. Psychological Reports, 48(3), 901-902.

Watt, J.D. (1991) Effect of boredom proneness on time perception. Psychological Reports, 69(1), 323-327.

Watt, J.D. and Blanchard, M.J. (1994) Boredom proneness and the need for cognition. Journal of Research in Personality, 28(1), 44-51.

Watt, J.D. and Ewing,J.E. (1996) Towards the development and validation of a measure of sexual boredom. Journal of Sex Research, 33(1), 57-66.

Watt, J.D. and Hargis, M.B. (2010) Boredom proneness: Its relationship with subjective underemployment, perceived organizational support and job performance. Journal of Business and Psychology, 25(1), 163-174.

Watt, J.D. and Vodanovich, S.J. (1992) An examination of race and gender differences in boredom proneness. Journal of Social Behavior and Personality, 7(1), 169175.

Watt, J.D. and Vodanovich, S.J. (1999) Boredom proneness and psychosocial Development. The Journal of Psychology, 133(3), 303-314.

Weiner, B. (1985) An attributional theory of achievement motivation and emotion. Psychological Review, 92(4), 548-573.

Weinerman, J. and Kenner, C. (2016) Boredom: That which shall not be named. Journal of Developmental Education, 40(1), 18-23.

Wienstein, L., Xie, X. and Cleanthous, C.C. (1995) Purpose in life, boredom and volunteerism in a group of retirees. Psychological Reports, 76(2), 482.

Williams C. (2015) Bored? Well don't be. Scientific American, 3036 (August), 37-41.

Willis, J. (2014) Neuroscience reveals that boredom hurts. Phi Delta Kappan, 95(8), 28-32.

Wink, P. and Donahue, K. (1997) The relation between two types of narcissism and boredom. Journal of Research in Personality, 31(1), 136-140. 
Wolfgang, M.E. and Dowling, W.D. (1981) Differences in motivation of adult and younger undergraduates. The Journal of Higher Education, 52(6), 640-648.

Wright, L.S. and Moore, R. (1982) Correlates of reported drug use among college undergraduates. Journal of Drug Education, 12(1), 65-73.

Zakay, D. (2014) Psychological time as information: The case of boredom. Frontiers in Psychology, 5(917), 1-5.

Zhou, M. and Kam, C.C.S. (2017) Trait procrastination, self-efficacy and achievement goals: The mediating role of boredom coping strategies. Educational Psychology: An International Journal of Experimental Educational Psychology, 37(7), 854-872.

Zondag, H.J. (2013) Narcissism and boredom revisited: An exploration of correlates of overt and covert narcissism among Dutch university students. Psychological Reports: Mental and Physical Health, 112(2), 563-576.

Zuckerman, M. (1979) Sensation seeking: Beyond the optimal level of arousal. Hillsdale, NJ: Lawrence Erlbaum Associates. 